\title{
Eutrophication of ancient Lake Ohrid: Global warming amplifies detrimental effects of increased nutrient inputs
}

\author{
Andreas Matzinger and Martin Schmid ${ }^{1}$
}

Swiss Federal Institute of Aquatic Science and Technology (Eawag), Seestrasse 79, CH-6047 Kastanienbaum, Switzerland

Elizabeta Veljanoska-Sarafiloska, Suzana Patceva, and Dafina Guseska

Hydrobiological Institute Ohrid, Naum Ohridski 50, MK-6000 Ohrid, Macedonia

Bernd Wagner ${ }^{2}$

Institute for Geophysics and Geology, University Leipzig, Talstrasse 35, D-04103 Leipzig, Germany

Beat Müller, Michael Sturm, and Alfred Wüest

Swiss Federal Institute of Aquatic Science and Technology (Eawag), Seestrasse 79, CH-6047 Kastanienbaum, Switzerland

\begin{abstract}
Lake Ohrid in southeastern Europe is one of the few ancient, long-lived lakes of the world, and contains more than 200 endemic species. On the basis of integrated monitoring of internal and external nutrient fluxes, a progressing eutrophication was detected $(\sim 3.5$-fold increase in phosphorus $(\mathrm{P})$ concentration in the lake over the past century). The lake is fortunately still oligotrophic, with high concentrations of dissolved oxygen (DO) in the deep water that are requisite for the unique endemic bottom fauna. Hypolimnetic DO is not only very sensitive to changes in anthropogenic P load-via mineralization of organic material — but also to global warming via decrease of vertical mixing and less frequent complete deep convection. Moreover, these two human effects amplify each other. To keep DO from falling below currently observed minimal levels - given the predicted atmospheric warming of $0.04^{\circ} \mathrm{C} \mathrm{yr}^{-1}$ — the $\mathrm{P}$ load must be decreased by $50 \%$ in coming decades. However, even with such a reduction in $\mathrm{P}$ load, anoxia is still expected toward the end of the century if the rate of warming follows predictions.
\end{abstract}

There are but a few ancient lakes that have provided favorable living conditions for freshwater organisms over time periods far beyond the usual. These ancient systems allowed the persistence and speciation of fauna and flora, acting as literal centers of evolution (Martens et al. 1994). Compared to short-lived lakes, they often developed extensive species endemism (Table 1). Most of the lakes in Table 1 are potentially threatened by cultural eutrophication (Beeton 2002); for Lake Victoria and Lake Biwa even possible species extinction has been reported (Seehausen et al. 1997; Tsugeki et al. 2003). Moreover, shifts toward nonendemic species have been observed in the

\footnotetext{
${ }^{1}$ Corresponding author (martin.schmid@eawag.ch).

2 Present address: Leibniz Institute for Baltic Sea Research, Seestr. 15, D-18119 Warnemünde, Germany.

Acknowledgments

This work was only possible thanks to the cooperation between the Hydrobiological Institute in Ohrid (HBI) and the Swiss Federal Institute of Aquatic Science and Technology (Eawag). Particular thanks to Z. Brdaroski, B. Cakalovski, I. Holderegger, D. Ilic-Boeva, M. Jordanoski, M. Krstanovska, T. Naumoski, K. Paloski, M. Schurter, B. Sinnet, Z. Spirkovski, R. Stierli, and A. Zwyssig for their great help in the field and the laboratory. An earlier version of the manuscript profited significantly from suggestions by $\mathrm{B}$. Wehrli and two anonymous reviewers.

The work was financially supported by the Swiss State Secretariat for Economic Affairs (seco) and the Swiss National Science Foundation Grant 2000-067091.01.
}

vicinity of polluted inflows to oligotrophic Lake Ohrid. To prevent future irreversible losses, it is therefore important to detect trends toward eutrophication in ancient lakes as early as possible to react in time (e.g., Bootsma and Hecky 1993).

Once the extent of cultural eutrophication is known, the choice of mitigation measures may be complicated by interactions with other impacts. Of particular concern is the predicted global warming, which will affect a wide range of lakes and may aggravate effects of eutrophication (Matzinger et al. 2006b; Schindler 2006). In summary, appropriate lake management needs to address the three questions (i) to what extent eutrophication has occurred, (ii) what are the timescales of past changes and steady-state conditions, and (iii) what $\mathrm{P}$ loads are acceptable and whether this limit is sensitive to global warming or other expected changes.

However, eutrophication is difficult to identify for most of the unique lakes listed in Table 1, due to (1) low phosphorus $(\mathrm{P})$ concentrations with variations in the range of measurement errors and (2) excessively long residence times. Thus it would take decades of high-quality measurements to detect eutrophication in the water column. Alternatively, nutrient input can be monitored. However, sensible input assessment again requires an enormous effort and may still be unreliable (Moosmann et al. 2005). Finally, the analysis of sediments provides an option to look into the history of eutrophication, but 
Table 1. Comparison of ancient lakes.

\begin{tabular}{|c|c|c|c|c|c|c|}
\hline Lake & $\begin{array}{l}\text { Age } \\
\left(10^{6} \mathrm{yr}\right)\end{array}$ & $\begin{array}{l}\text { Endemic species described } \\
\text { (Number) }\end{array}$ & $\begin{array}{l}\text { Residence time* } \\
\text { (Yr) }\end{array}$ & $\begin{array}{l}\text { Max. depth } \\
\text { (m) }\end{array}$ & $\begin{array}{c}\mathrm{TP} \\
\left(\mathrm{mg} \mathrm{m}^{-3}\right)\end{array}$ & Sources \\
\hline Baikal & $25-30$ & 982 & 350 & 1,636 & $\sim 8^{\dagger}$ & $\begin{array}{l}\text { Shimaraev et al. 1994; Martens et al. } \\
\text { 1994; Goldman et al. } 1996\end{array}$ \\
\hline Tanganyika & $\sim 20$ & 632 & $7,000(1,600 *)$ & 1,470 & $1.9 *$ & $\begin{array}{l}\text { Martens et al. 1994; Järvinen et al. } \\
\text { 1999; Bootsma and Hecky } 2003\end{array}$ \\
\hline Malawi & $>2$ & $\sim 620$ & $650(450 *)$ & 700 & $9.3 *$ & $\begin{array}{l}\text { Martens et al. 1994; Guildford and } \\
\text { Hecky 2000; Bootsma and Hecky } \\
2003\end{array}$ \\
\hline Victoria & $0.015-0.75^{\S}$ & $\sim 240$ & 140 & 79 & 77.5 & $\begin{array}{l}\text { Martens et al. 1994; Guildford and } \\
\text { Hecky 2000; Bootsma and Hecky } \\
2003\end{array}$ \\
\hline Titicaca & $\sim 3$ & 61 & 660 & 284 & $24^{\dagger}$ & $\begin{array}{l}\text { Wurtsbaugh et al. 1992; Martens et al. } \\
\text { 1994; Grove et al. } 2003\end{array}$ \\
\hline Biwa & $0.4-1$ & 54 & 5.5 & 104 & 9 & Martens et al. 1994 \\
\hline Ohrid & $2-3$ & 210 & 70 & 289 & 4.6 & $\begin{array}{l}\text { Stankovic 1960; updated for selected } \\
\text { groups by Jerkovic 1972; Kenk } \\
\text { 1978; Gilbert and Hadzisce 1984; } \\
\text { Martens et al. } 1994\end{array}$ \\
\hline
\end{tabular}

\footnotetext{
* Defined as volume per outflow.

SRP during main mixing in July (L. Baikal) and September (L. Titicaca).

$\$$ Upper, oxygenated layer.

${ }^{\S}$ Large range due to different opinions regarding extent of past desiccation events.
}

results can only be interpreted in combination with additional information, such as input measurements or historic pollution records (Schelske and Hodell 1995). The scientific challenge contrasts the often limited research resources of the local institutions investigating those lakes of Table 1.

In this article we present an example of such an assessment for ancient Lake Ohrid (Macedonia/Albania; Fig. 1), using results from $\mathrm{P}$ monitoring and model simulations. In a preliminary assessment Matzinger et al. (2006b) estimated sensitivities of Lake Ohrid to different human impacts by reviewing their potential effects on physical processes. They found specifically that dissolved oxygen (DO) in the deep water may be not only highly sensitive to eutrophication but also to global warming. DO availability is a key parameter for the predominantly bottom-dwelling endemic organisms of Lake Ohrid (Stankovic 1960). As a result, anoxic conditions would reduce the habitat for many species, in particular the ones that are limited to large depths (e.g., several endemic forms of amphipods, ostracods, and oligochaetes; Stankovic 1960). Moreover, higher trophic state is expected to worsen oxygen conditions in the sediment throughout the lake. The present paper advances by the next two logical steps to quantify the potential severity of worsened DO conditions in Lake Ohrid.

In the first part of the paper the extent and dynamics of eutrophication is assessed. It is based on P, the limiting element in Lake Ohrid, with total phosphorus (TP) concentrations $\sim 4.6 \mathrm{mg} \mathrm{m}^{-3}$ and molar ratios of total nitrogen TN:TP > 50 (Guildford and Hecky 2000). P measurements in inflows, water column, and sediments are used to establish the contemporary lake-internal $\mathrm{P}$ balance. In a second step, timescales of past changes and a potential steady state are discussed on the basis of a linear P model to answer questions (i) and (ii) above.

In the second part of the paper, a dynamical model is established on the basis of the P balance (1) to quantify DO availability for different future eutrophication and global warming scenarios, as well as their interactions and (2) to define allowable $\mathrm{P}$ loads depending on these human impacts and DO requirements (question iii).

\section{Lake Ohrid}

Lake Ohrid is a transboundary lake shared by Macedonia and Albania (Fig. 1), situated between mountain ranges to the east and west. It is oligotrophic, deep (max. depth $\sim 289 \mathrm{~m}$ ), large (surface area $\sim 358 \mathrm{~km}^{2}$ ), and one of the most voluminous lakes $\left(\sim 55 \mathrm{~km}^{3}\right)$ in Europe (Table 2). The water balance is dominated by inflow from karst aquifers $(\sim 50 \%)$ with smaller shares from runoff and direct precipitation (Matzinger et al. 2006b). The fraction of river runoff had even been less than $10 \%$ before 1962, when River Sateska was deliberately diverted into the lake to reduce siltation in downstream reservoirs (Fig. 1). The karst aquifers are charged from mountain range precipitation and from Lake Prespa, which has no surface outflow (Fig. 1; Eftimi and Zoto 1997; Matzinger et al. 2006a). Via this underground connection to Lake Prespa the lake catchment extends also to Greece.

The top 150 - to $200-\mathrm{m}$ water column of Lake Ohrid follows the usual thermal stratification seasonality of deep, temperate lakes, whereas the lower hypolimnion is stably stratified by salinity (Fig. 2a). The stability due to the salinity gradient - although very weak - allows complete, deep convective mixing (in the following referred to as "complete overturn") only roughly once every 7 yr during 


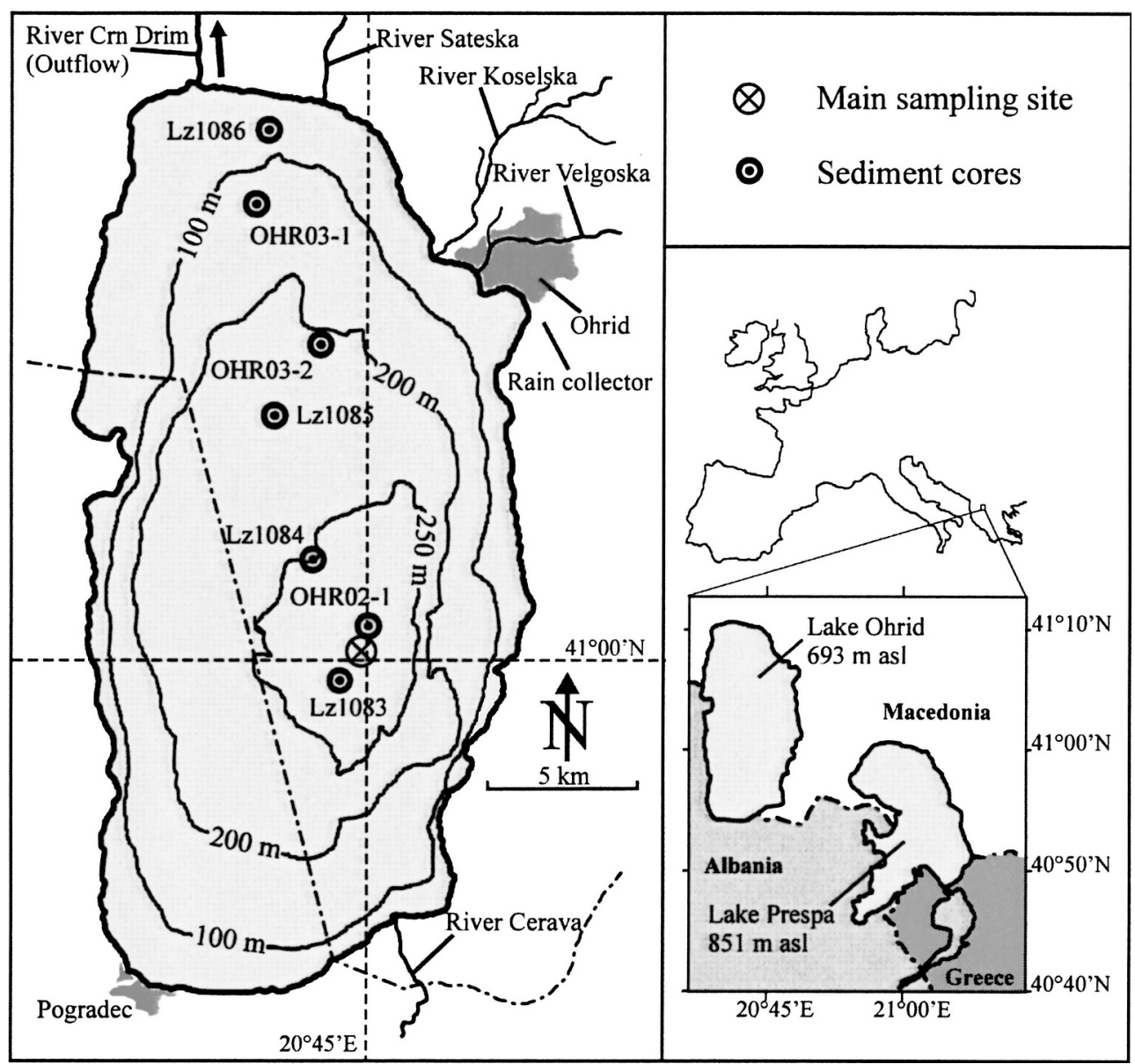

Fig. 1. Geographical overview. The inset maps indicate the location of Lake Ohrid within Europe and the Macedonian-Albanian-Greek triangle.

cold winters (Hadzisce 1966; Matzinger et al. 2006b). Figure 3 shows the change in different water properties for such an event in winter 2003/2004. In the absence of cold winters, geothermal heat input and turbulent vertical exchange steadily raise hypolimnion temperature, making complete overturn more probable as time progresses (Fig. 3b). In turn salinity (S) and DO show a seasonal

Table 2. Lake Ohrid characteristics.

\begin{tabular}{|c|c|c|}
\hline Property & Unit & Value \\
\hline Latitude & ${ }^{\circ} \mathrm{N}$ & 41.1 \\
\hline Longitude & ${ }^{\circ} \mathrm{E}$ & 20.7 \\
\hline Altitude & $\mathrm{m}$ asl & 690 \\
\hline $\begin{array}{l}\text { Catchment area } \\
\quad \text { (including Lake Prespa) }\end{array}$ & $\mathrm{km}^{2}$ & 2,600 \\
\hline Surface area & $\mathrm{km}^{2}$ & 358 \\
\hline Volume & $\mathrm{km}^{3}$ & 54.9 \\
\hline Maximal depth & $\mathrm{m}$ & 288.7 \\
\hline Average depth & $\mathrm{m}$ & 155 \\
\hline Average annual inflow & $\mathrm{m}^{3} \mathrm{~s}^{-1}$ & 38 \\
\hline Average annual outflow & $\mathrm{m}^{3} \mathrm{~s}^{-1}$ & 25 \\
\hline Mean water residence time & $\mathrm{yr}$ & 70 \\
\hline $\begin{array}{l}\text { Average phosphorus } \\
\text { concentration }\end{array}$ & $\mathrm{mg} \mathrm{m}^{-3}$ & 4.6 \\
\hline
\end{tabular}

trend because of summer productivity and increased turbulence in winter (Fig. 3c,d). DO stays always high throughout the water column with a maximum between 20 and $40 \mathrm{~m}$ depth as a result of phytoplankton production (Fig. 2b).

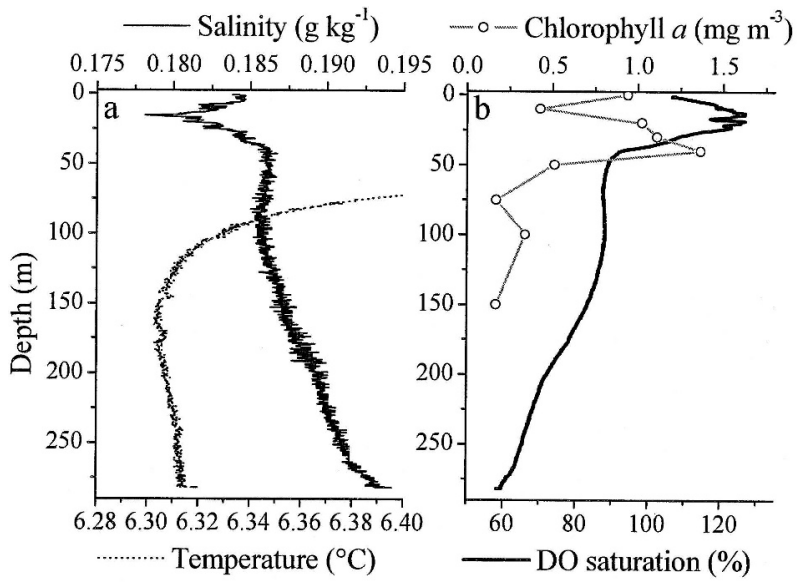

Fig. 2. Typical summer profiles of (a) salinity and temperature, and (b) chlorophyll $a$ and DO saturation from Lake Ohrid (30 Jun 2003). 


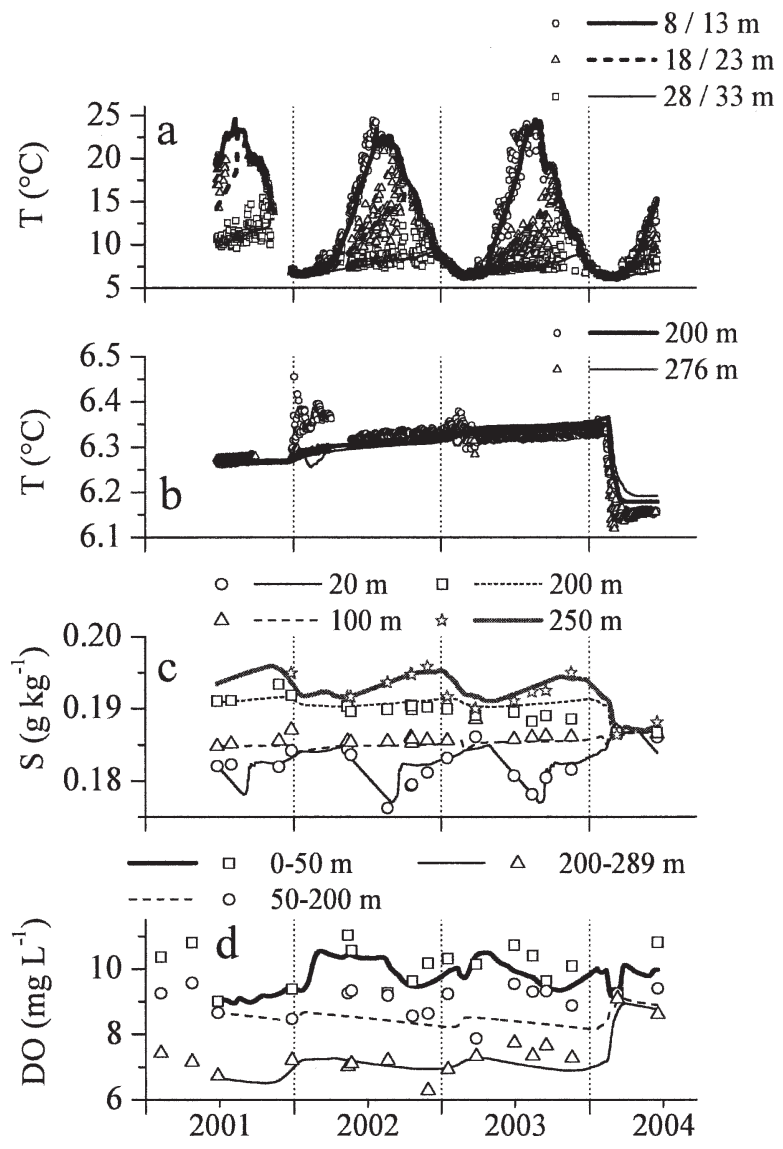

Fig. 3. (a and b) Temperature, (c) salinity, and (d) dissolved oxygen for different depths (see legend) over the period of observation. Symbols are measurements (from thermistors for $T$ and from CTD profiles for S and DO), lines are simulated results. The reason for the high temperature signal in 200-m depth in panel (b) at the beginning of 2002 is unknown; most probably it is connected to subaquatic spring inflows.

Clearly the most spectacular quality of the lake is its impressive endemism. Similar to Lake Baikal, it harbors endemic species covering the whole food chain, from phytoplankton (e.g., Cyclotella fottii) over zooplankton (e.g., Cyclops ochridanus), cyprinid fish (e.g., Pachychilon pictus), to predatory fish (e.g., Salmo letnica), and finally its diverse endemic bottom fauna (e.g., Ochridagammarus solidus) (review in Salemaa 1994). Whereas most of the endemic species descriptions are based on morphological and ecological characteristics, some recent applications of molecular genetic techniques underline the difference of the Ohrid fauna from common European taxa (e.g., Sell and Spirkovski 2004).

\section{Materials and methods}

Water analysis - Regular water samples were taken from Lake Ohrid, its tributaries, and collected rainwater from 2001/2002 to 2004 (Fig. 1, Table 3). Samples were stored in new or acid-rinsed plastic bottles and cooled for transport. $\mathrm{TP}, \mathrm{TN}$, soluble reactive phosphorus (SRP), and nitrate $\left(\mathrm{NO}_{3}^{-}\right)$were analyzed colorimetrically using standard analytical methods (DEW 1996). Mean measurement errors were $1.9 \mathrm{mg} \mathrm{m}^{-3}$ for $\mathrm{TP}, 28 \mathrm{mg} \mathrm{m}^{-3}$ for $\mathrm{TN}$, $0.6 \mathrm{mg} \mathrm{m} \mathrm{m}^{-3}$ for SRP, and $4 \mathrm{mg} \mathrm{m}^{-3}$ for $\mathrm{NO}_{3}^{-}$.

In addition, profiles were taken in Lake Ohrid with a Seabird SBE 19 CTD. Parameters included water temperature, in situ conductivity $\kappa_{T}, \mathrm{pH}$, and DO. On the basis of an analysis of major ionic composition of Lake Ohrid water (IC 690 equipped with a Super-Sep column for cations, IC 733 with 753 suppression module for anions; all Metrohm; methods in Weiss 2004), $\kappa_{T}$ values were transformed to conductivity at $20^{\circ} \mathrm{C}$ and to salinity (Wüest et al. 1996). CTD DO values were calibrated using the Winkler method.

Plankton sampling-Plankton samples for quantitative analysis were taken with Niskin bottles covering the whole water column of Lake Ohrid down to $150 \mathrm{~m}$ (Table 3). Species were identified and counted under the microscope. Phytoplankton biomass was calculated from photometric chlorophyll $a$ analyses, using the relation proposed by Marshall and Peters (1989) (detailed methods in Patceva 2005). Zooplankton biomass was based on detailed assessment of numbers and biovolumes of all major zooplankton species and their different stages (Eudiaptomus gracilis, Arctodiaptomus steindachneri, Cyclops ochridanus, Mesocyclops leuckarti, Daphnia pulicaria) for the year 2000 (detailed methods in Guseska 2003).

Sediment analysis-Three sediment cores OHR03-1, OHR03-2, and OHR02-1 were retrieved from 122-, 202-, and 280-m depths, along the north-south axis of the lake (Fig. 1, Table 3), using a gravity corer (Kelts et al. 1986) and subsequently sectioned to $0.5-$ to 2 -cm-long vertical segments. For each segment, the water content was measured by weight loss after freeze-drying. TP was measured photometrically after digestion with $\mathrm{K}_{2} \mathrm{~S}_{2} \mathrm{O}_{8}$ in an autoclave for $2 \mathrm{~h}$ at $120^{\circ} \mathrm{C}$ (DEW 1996). Total carbon (TC) and TN were analyzed with a combustion CNSAnalyzer (EuroVector Elemental Analyzer). Total inorganic carbon (TIC) was measured by infrared absorption of $\mathrm{CO}_{2}$ after acidifying the sample with $3 \mathrm{~mol} \mathrm{~L}^{-1} \mathrm{HCl}$ (Skoog et al. 1996). Total organic carbon (TOC) was calculated as TOC $=$ TC - TIC.

For consistency check, four additional cores Lz1083 to Lz1086 were taken from 270-, 250-, 232-, and 85-m depths in 2004 (Fig. 1, Table 3). Vertical 2-cm segments were equally freeze-dried and analyzed using a VARIO elemental CNS analyzer for TC and TN. TOC content was measured with a Metalyt CS 1000S (ELTRA Corp.) analyzer, after pretreating the sediment with $10 \% \mathrm{HCl}$ at $80^{\circ} \mathrm{C}$ to remove carbonate. Finally TIC was calculated indirectly from TOC and TC.

For the dating of the core OHR02-1 ${ }^{137} \mathrm{Cs}$ and ${ }^{210} \mathrm{~Pb}$ activities were established from gamma-counting in Ge-Li borehole detectors (Hakanson and Jansson, 1983). As no clear peaks could be identified in the ${ }^{137} \mathrm{Cs}$ profile, only ${ }^{210} \mathrm{~Pb}$ was used. In the top $2 \mathrm{~cm}$ of the core, the ${ }^{210} \mathrm{~Pb}$ activity was practically constant, probably because of bioturbation by benthic organisms. Below the homogeneous layer, the ${ }^{210} \mathrm{~Pb}$ signal decreased exponentially to background activity. 
Table 3. Monitoring of Lake Ohrid.

\begin{tabular}{|c|c|c|c|}
\hline Site & Sampling period & $\begin{array}{l}\text { Number of } \\
\text { samples }\end{array}$ & Parameters \\
\hline $\begin{array}{l}\text { Lake water column }(0,10,20,30,40 \\
\quad 50,75,100,150,200,250,275 \mathrm{~m})\end{array}$ & Feb 2001-Jun 2004 & $\begin{array}{r}118 \\
23 \\
8 \\
1 \\
40\end{array}$ & $\begin{array}{l}\mathrm{SRP}, \mathrm{TP}, \mathrm{DO} \\
\mathrm{NO}_{3}^{-} \\
\mathrm{TN} \\
\mathrm{Na}^{+}, \mathrm{K}^{+}, \mathrm{Ca}^{2+}, \mathrm{Mg}^{2+}, \mathrm{Cl}^{-}, \mathrm{SO}_{4}^{2-} \\
\mathrm{CTD} \text { profiles }(\sim 0.2 \mathrm{~m} \text { depth resolution })\end{array}$ \\
\hline $\begin{array}{l}\text { Phytoplankton samples } \\
\quad(0,10,20,30,40,50,75,100,150 \mathrm{~m})\end{array}$ & Mar 2001-Nov 2003 & 155 & Abundance, chlorophyll $a$ \\
\hline $\begin{array}{l}\text { Zooplankton samples } \\
\quad(0,10,20,30,40,50,75,100,150 \mathrm{~m})\end{array}$ & Jan 2000-Dec 2000 & 108 & Abundance, biovolume \\
\hline $\begin{array}{l}\text { Sediment cores } \\
\text { OHR02-1, OHR03-1, OHR03-2 (Fig. 1) }\end{array}$ & May 2002 \& Apr 2003 & $\begin{array}{r}140 \\
76 \\
13\end{array}$ & $\begin{array}{l}\text { TC, TIC, TN, water content } \\
\text { TP } \\
{ }^{137} \mathrm{Cs},{ }^{210} \mathrm{~Pb}\end{array}$ \\
\hline $\begin{array}{l}\text { Sediment cores Lz1083, Lz1084, } \\
\text { Lz1085, Lz1086 (Fig. 1) }\end{array}$ & Jun 2004 & 151 & TC, TOC, TN, water content \\
\hline $\begin{array}{l}\text { Sediment traps at main sampling site } \\
\quad(69,109,149,199,249,275 \mathrm{~m})\end{array}$ & Feb 2001-Sep 2003 & 30 & TC, TIC, TN, TP \\
\hline River Velgoska (Fig. 1) & Oct 2002-Nov 2003 & $\begin{array}{r}3 \\
7 \\
9 \\
304\end{array}$ & $\begin{array}{l}\text { TP } \\
\text { SRP } \\
\text { Discharge } \\
\text { Water level }\end{array}$ \\
\hline River Koselska (Fig. 1) & Oct 2002-Nov 2003 & $\begin{array}{r}2 \\
6 \\
9 \\
360\end{array}$ & $\begin{array}{l}\text { TP } \\
\text { SRP } \\
\text { Discharge } \\
\text { Water level }\end{array}$ \\
\hline River Sateska (Fig. 1) & Oct 2002-May 2004 & $\begin{array}{r}25 \\
8 \\
25\end{array}$ & $\begin{array}{l}\text { TP, SRP } \\
\text { Discharge } \\
\text { Water level }\end{array}$ \\
\hline $\begin{array}{l}\text { Eight Albanian tributaries } \\
\text { Rain samples }\end{array}$ & $\begin{array}{l}\text { Oct } 2002 \\
\text { Oct } 2002-\text { Nov } 2003\end{array}$ & $\begin{array}{r}8 \\
24 \\
5\end{array}$ & $\begin{array}{l}\text { TP, SRP, Discharge } \\
\text { SRP } \\
\text { TP }\end{array}$ \\
\hline
\end{tabular}

Sediment mass flux was calculated using:

$$
S_{\mathrm{M}}=(1-\mathrm{POR}) \times \operatorname{sed} \times \rho_{\mathrm{sed}}
$$

where $S_{\mathrm{M}}\left(\mathrm{kg} \mathrm{m}^{-2} \mathrm{yr}^{-1}\right)$ is sedimentation of dry matter, POR (no units) is porosity calculated from the water content, sed $\left(\mathrm{m} \mathrm{yr}^{-1}\right)$ is the sediment accumulation rate from ${ }^{210} \mathrm{~Pb}$ dating, and $\rho_{\text {sed }}=2,600 \mathrm{~kg} \mathrm{~m}^{-3}$ is the sediment density from Ohrid cores established by pycnometer. The average $S_{\mathrm{M}}$ in the dated section of the core (top $8 \mathrm{~cm}$, $\sim 100 \mathrm{yr}$ ) was used to calculate sedimentation of TP, TN, TOC, and TIC by multiplication with their respective measured mass fractions.

Apart from cores, sediment was collected by six sediment traps at the main sampling site (Fig. 1, Table 3). Traps were emptied twice per year from 2001 to 2003. Before chemical analysis, as for the OHR cores, sediment mass was determined after drying the samples at $30^{\circ} \mathrm{C}$.

Assessment of phosphorus loads-For the three main tributaries, rivers Velgoska, Koselska, and Sateska (Fig. 1), discharge measurements have been performed with a SEBA Universal Current Meter F1. To reach a higher resolution of river discharge, water levels were read regularly and calibrated with occasional discharge measurements (Table 3). For the calculation of TP loads, rating curves were established using a linear fit for River Velgoska, which is influenced mainly by point sources, and the concentration (C)-discharge $(Q)$ relation $C=k_{1} / Q+k_{2} \times \ln \left(Q+k_{3}\right)$ (Moosmann et al. 2005) for rivers Koselska and Sateska, which are influenced both by point and diffuse sources. On the basis of the rating curves, $\mathrm{P}$ loads were calculated and integrated using daily flow readings for rivers Velgoska and Koselska and average monthly discharge for River Sateska from Ivanova (1974) and the Macedonian Hydrometeorological Institute (unpublished data). For a second estimate of P loads, measured $C-Q$ pairs since 1996 [from this monitoring, Naumoski (2000) and Veljanoska-Sarafiloska (2002)] were combined and integrated over $1 \mathrm{yr}$.

Eight Albanian tributaries were sampled on one excursion after several rainy days. Flow was estimated through water speed and cross-sectional river area.

Finally rain samples were collected on the roof of the Hydrobiological Institute in Ohrid using a funneled plastic collector, which was emptied after every rain event (Fig. 1).

Linear phosphorus model-To check the calculated P budget and estimate historic concentrations, the linear model by Vollenweider (1969) was used:

$$
\frac{\partial\langle\mathrm{TP}\rangle}{\partial t}=\frac{1}{V} \times \mathrm{P}_{i n p}-\sigma \times\langle\mathrm{TP}\rangle-\frac{\beta}{\tau} \times\langle\mathrm{TP}\rangle
$$

where $<\mathrm{TP}>\left(\mathrm{mg} \mathrm{m}^{-3}\right)$ is the volume-averaged concentra- 
Table 4. Phosphorus balance.

\begin{tabular}{|c|c|c|c|}
\hline Parameter & Method & $\begin{array}{l}\text { Total } \mathrm{P}^{*} \\
\left(\mathrm{t} \mathrm{yr}^{-1}\right)\end{array}$ & $\begin{array}{l}\text { Potential bioavail. } \mathrm{P}^{*} \\
\left(\mathrm{t} \mathrm{yr}^{-1}\right)\end{array}$ \\
\hline \multicolumn{4}{|l|}{ External balance } \\
\hline $\begin{array}{l}\text { External P loads from rivers, rain, } \\
\text { groundwater }\end{array}$ & $C-Q$ measurements & $32 \pm 5$ & $27 \pm 5$ \\
\hline \multicolumn{4}{|l|}{ Internal balance } \\
\hline $\mathrm{P}$ input & From balance & $99 \pm 15$ & $47 \pm 15$ \\
\hline $\mathrm{P}$ gross sedimentation & Sediment core $0-2 \mathrm{~cm}$ & $128 \pm 11$ & $76 \pm 11$ \\
\hline $\mathrm{P}$ net sedimentation & Sediment core $2-4 \mathrm{~cm}$ & $96 \pm 15$ & $44 \pm 15$ \\
\hline \multirow{2}{*}{$\mathrm{P}$ release from sediment } & SRP increase in lake & $25 \pm 4$ & $25 \pm 4$ \\
\hline & Sediment core & $32 \pm 16$ & $32 \pm 16$ \\
\hline
\end{tabular}

${ }^{*}$ Indicated errors are standard deviations among different profiles, cores, sediment trap periods, or P load estimates.

tion of TP, $<\mathrm{TP}>/ \mathrm{t}\left(\mathrm{mg} \mathrm{m}^{-3} \mathrm{yr}^{-1}\right)$ is the rate of change of $<\mathrm{TP}\rangle, V\left(\mathrm{~m}^{3}\right)$ is the lake volume, $\tau(\mathrm{yr})$ is the average

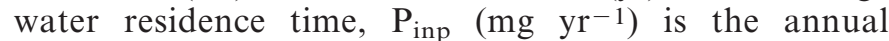
phosphorus input, net sedimentation is assumed proportional to the total phosphorus content with the sedimentation rate $\sigma\left(\mathrm{yr}^{-1}\right)$, and the outflow of TP is expressed by the discharge $(V / \tau)$ times the average surface concentration $\beta \times<\mathrm{TP}>$ (where $\beta=\mathrm{TP}_{\text {surface }} /<\mathrm{TP}>$ ). Following a change in $\mathrm{P}_{\text {inp }}$, current TP concentration $<\mathrm{TP}>(t=0)$ will approach a new equilibrium $\langle\mathrm{TP}\rangle(t=\infty)$ with $<\mathrm{TP}>(t)=\left\langle\mathrm{TP}>(\infty)+[<\mathrm{TP}>(0)-<\mathrm{TP}>(\infty)] \times \mathrm{e}^{-\mathrm{t} \times}\right.$ $(\beta / \tau+\sigma)$. The residence time of $P$ in the lake is then $\tau_{P}{ }^{*}=[(\beta /$ $\tau)+\sigma]^{-1}$ and $<\mathrm{TP}>(\infty)=\tau_{\mathrm{P}}{ }^{*} \times \mathrm{P}_{\text {inp }} / V$.

Dynamic modelling-For the evaluation of different future eutrophication and global warming scenarios the physical lake model by Goudsmit et al. (2002) was combined with an adapted version of the biogeochemical lake model by Omlin et al. (2001), implemented with the simulation software AQUASIM (Reichert 1994). The model includes temperature (T), S, P, DO, total phytoplankton, total zooplankton, and dead organic matter as model variables. In terms of biogeochemical processes, primary production, growth of zooplankton, respiration, aerobic mineralization in the water column and at the sediment, as well as death and P-adsorption to settling particles are taken into account. The model was calibrated for observed $\mathrm{T}$ and $\mathrm{S}$, measured balances of $\mathrm{P}, \mathrm{DO}$, and organic matter, as well as historic data for primary production (Fig. 3). A detailed presentation of model equations and calibration is given in Web Appendix 1 (http://www.aslo.org/lo/toc/vol_52/issue_1/0353a1.pdf).

\section{Contemporary phosphorus balance}

A summarized overview of the following $\mathrm{P}$ balance is given in Table 4.

External phosphorus loads- $\mathrm{P}$ was monitored in the catchment (1) to quantify $\mathrm{P}$ inputs and (2) to identify the main contributors. Inputs are expected from direct pre- cipitation, dry deposition, groundwater inflows, tributaries, and diffusive sources, such as agricultural activities and settlements close to the lake shore. The calculated P loads are summarized in Table 5. In total, an integrated SRP input of $\sim 27 \mathrm{t} \mathrm{yr}^{-1}$ from tributaries, groundwater, and rain was found.

In rain samples collected close to the town of Ohrid over $1 \mathrm{yr}$ (Fig. 1), average SRP of $\sim 8.4 \pm 1.6 \mathrm{mg} \mathrm{m}^{-3}$ was found, which is in the range of sites with minor anthropogenic influence, such as Lake Malawi (Bootsma and Hecky 1993) or northeastern Crete (Markaki et al. 2003). The measured value also contains SRP that may have leached from dry deposition, given the time between rain event and actual sample collection, which was typically several hours (Herut et al. 1999). Few samples on which also TP was measured (though without prior stirring) indicate that the load of inert particulate $\mathrm{P}$ is at least one order of magnitude larger than for SRP.

The contribution of groundwater depends on the amount of water stemming from Lake Prespa and the $\mathrm{P}$ retention capacity of the underground karst connection. Matzinger et al. (2006a) found SRP $\sim 10.9 \pm 2.6 \mathrm{mg} \mathrm{m}^{-3}$ for the $7.8 \mathrm{~m}^{3} \mathrm{~s}^{-1}$ flow from Lake Prespa and SRP $\sim 4.0 \pm$ $0.9 \mathrm{mg} \mathrm{m}^{-3}$ for the precipitation-fed remainder, which add up to a total groundwater load of $\sim 4.2 \mathrm{t} \mathrm{yr}^{-1}$.

$\mathrm{P}$ load of River Velgoska is dominated by point sources, as can be observed in $\mathrm{P}$ dilution with discharge (Fig. 4), leading to an extreme increase in SRP over the mere $5 \mathrm{~km}$ from source to mouth (Fig. 5). In contrast, River Sateskaby far the largest tributary-shows an increase in $\mathrm{P}$ with higher flow in Fig. 4, indicating that leaching and erosion from agricultural soils are important (Gächter et al. 2004). Finally, River Koselska is influenced both by agriculture and point sources with increased concentrations at low and high discharge (Fig. 4). The expected moderate SRP increase along the river is diluted effectively by more pristine tributaries (Fig. 5).

For all three rivers, differences between $\mathrm{P}$ loads from direct integration and rating-curve estimates were smaller than $10 \%$. These small deviations may be attributed to a reduced influence from agriculture-based pollution 
Table 5. External P loads to Lake Ohrid.

\begin{tabular}{|c|c|c|c|c|}
\hline \multirow[b]{2}{*}{ Source } & \multicolumn{2}{|c|}{ Status quo } & \multicolumn{2}{|c|}{ Historic situation $(>200 \mathrm{yr}$ ago) } \\
\hline & $\begin{array}{l}\text { Mean annual inflow* } \\
\left(\mathrm{m}^{3} \mathrm{~s}^{-1}\right)\end{array}$ & $\begin{array}{l}\text { SRP load } \\
\left(\mathrm{t} \mathrm{yr}^{-1}\right)\end{array}$ & $\begin{array}{l}\text { Mean annual inflow* } \\
\left(\mathrm{m}^{3} \mathrm{~s}^{-1}\right)\end{array}$ & $\begin{array}{l}\text { P-load } \\
\left(\mathrm{t} \mathrm{yr}^{-1}\right)\end{array}$ \\
\hline Precipitation on lake surface & 8.8 & $2.3 \pm 0.4$ & 8.8 & 2.3 \\
\hline Groundwater inflow & 20.2 & $4.2 \pm 0.7$ & $\sim 24.4$ & $4.0 \pm 0.6$ \\
\hline Tributaries: & & & & \\
\hline River Velgoska & 0.4 & $5.8 \pm 0.4$ & & \\
\hline River Koselska & 1.3 & $1.0 \pm 0.1$ & & \\
\hline River Sateska & 5.5 & $\begin{array}{l}0.6 \pm 0.6 \\
(5.8 \pm 0.6 \mathrm{TP})\end{array}$ & & \\
\hline River Cerava & 0.2 & $0.3 \pm 0.15 \S$ & & \\
\hline Small creeks from Macedonia & 1.0 & $0.9 \pm 0.9$ & & \\
\hline Albanian tributaries & 0.5 & $12.1 \pm 4.0$ & & \\
\hline Total tributaries & 8.9 & 25.9 & 3.9 & $7.2 \|$ \\
\hline Total & 37.9 & 32.4 & 37.1 & 13.5 \\
\hline
\end{tabular}

${ }^{*}$ From Matzinger et al. $(2006 b)$.

$\dagger$ Errors represent standard deviation among measurements for precipitation and groundwater, and deviations among methodologies for tributaries.

\$ From Matzinger et al. (2006a).

§ Based on Naumoski (2000).

" Including point sources.

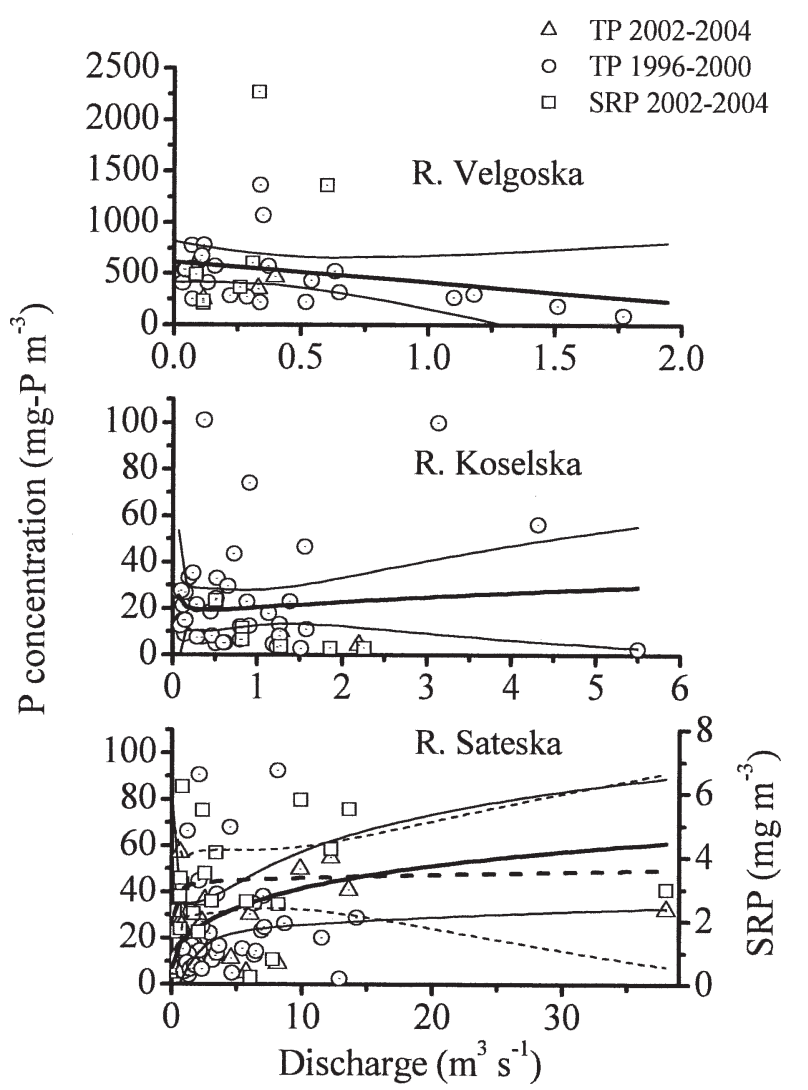

Fig. 4. Measured TP and SRP concentrations versus discharge of three tributaries (Fig. 1). Data from 1996 to 2000 are from Naumoski (2000) and Veljanoska-Sarafiloska (2002). Bold lines are least-square fitted rating curves using the concentration (C)-discharge $(Q)$ relation $C=k_{1} / Q+k_{2} \times \ln \left(Q+k_{3}\right)$ and a linear relation for River Velgoska. Thin lines are $95 \%$ confidence limits. For River Sateska SRP concentrations are on a separate axis (right) and the respective fitted curve and confidence limits are shown with dashed lines. compared to central European streams examined by Moosmann et al. (2005). For the remaining Macedonian tributaries, rough estimates are given using average Sateska $\mathrm{P}$ concentrations or based on measurements for River Cerava (Naumoski 2000). The Albanian catchment consists mainly of small creeks with large seasonal flow variations, some of which are severely polluted. As a result two creeks at the town of Pogradec contribute $\sim 90 \%$ of the SRP input from Albanian tributaries. Given this dominance of permanent point sources on the Albanian side, it can be assumed that the measurements after several days of rain reflect the daily household pollution quite accurately.

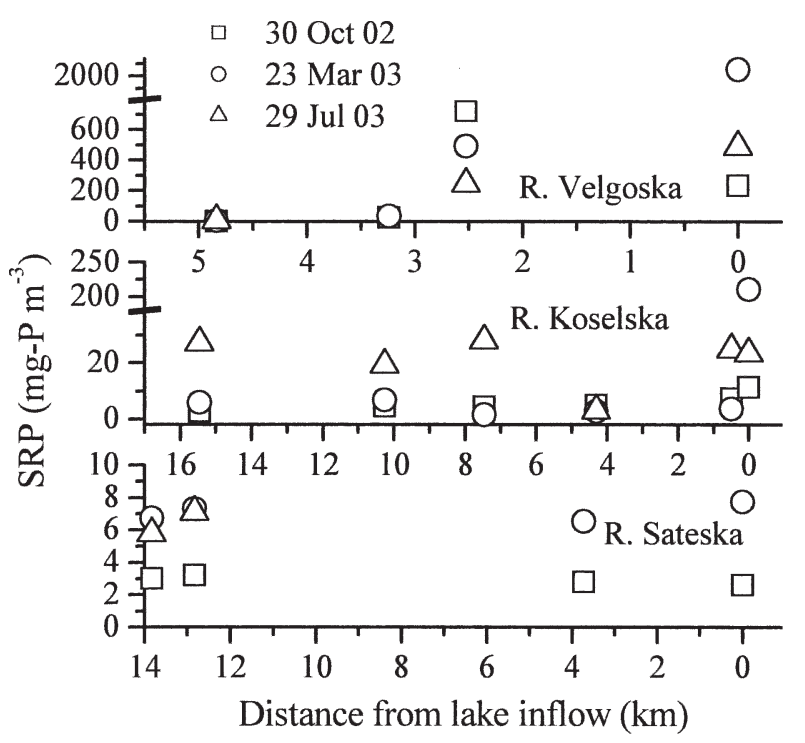

Fig. 5. Change in SRP concentrations of three tributaries as a function of distance from their mouth (Fig. 1). Note breaks on $y$-axis in top two graphs. Missing symbols for River Sateska in July 2003 indicate that riverbed was dry at the sampling point. 


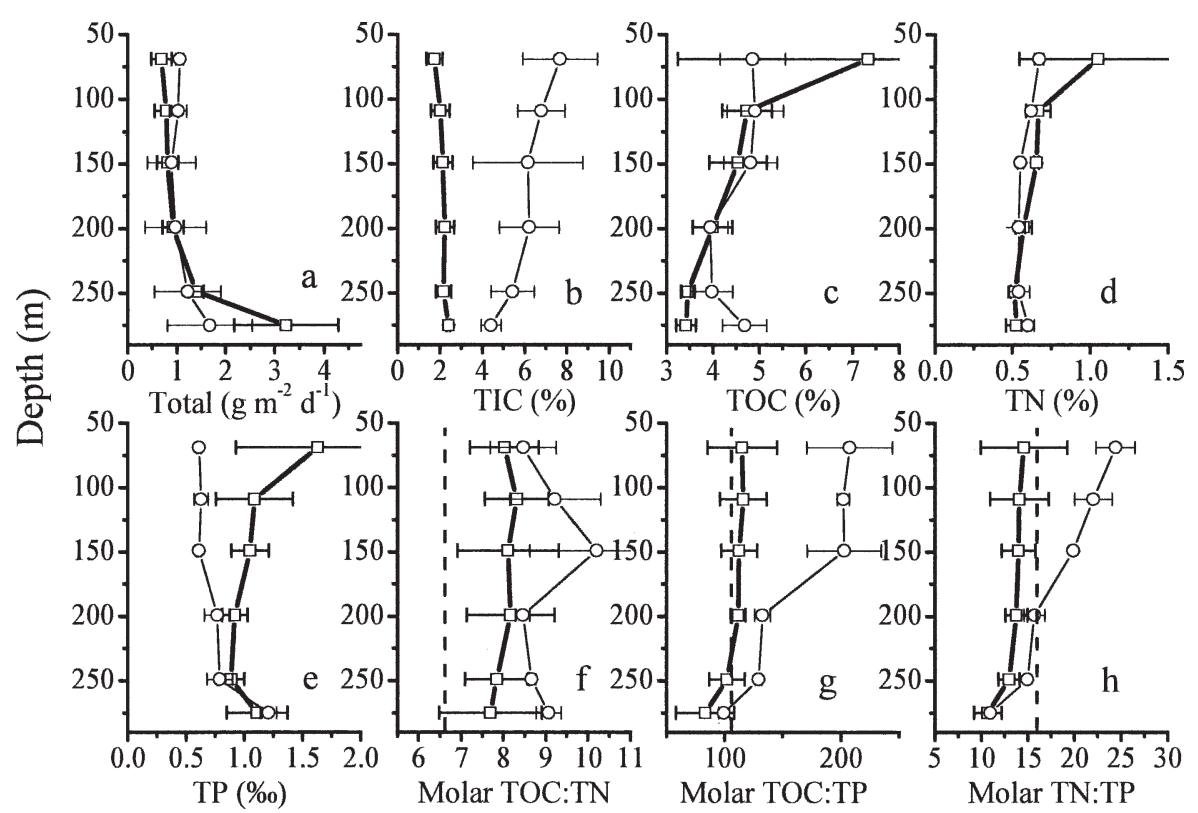

Fig. 6. Data from sediment traps. Squares for winter season (three periods: 07 Feb 2001 to 25 Apr 2001, 27 Dec 2001 to 14 May 2002, 21 Oct 2002 to 27 Mar 2003), circles for summer season (two periods: 23 May 2002 to 21 Oct 2002, 27 Mar 2003 to 16 Sep 2003). Error bars show standard deviations of averaged periods. (a) shows sedimentation as dry mass per area and time; (b) to (h) describe contents of trap material. Dashed lines in (f) to (h) indicate Redfield ratio $(\mathrm{C}: \mathrm{N}: \mathrm{P}=106: 16: 1)$.

Phosphorus outputs-The P balance can be alternatively calculated via its loss terms. P output via the only outflow, the River Crn Drim (Fig. 1), amounts to $\sim 3 \mathrm{t} \mathrm{yr}^{-1}$, calculated from surface concentrations and flow rate. In comparison, $\mathrm{P}$ loss to the sediment requires a more elaborate analysis.

Sediment traps were placed in Lake Ohrid over two full annual cycles to estimate gross $\mathrm{P}$ sedimentation and to better understand internal lake cycling (Fig. 6). As the top trap was still in the trophogenic zone and the lowest was subject to focusing, the intermediate four traps were used for the estimation of lake-wide vertical fluxes. Sedimentation was unexpectedly constant throughout the seasons as well as interannually (Fig. 6a), with an average gross $\mathrm{P}$ sedimentation of $110 \mathrm{t} \mathrm{yr}^{-1}$. Surprisingly, almost $60 \%$ of this amount was found during the less productive winter season (Fig. 6e), when phytoplankton density in the lake drops to about $10 \%$ of its summer maximum (Patceva 2005) and TIC amounts to $1 / 3$ of the sedimentation in summer (Fig. 6b). The three times higher TIC values during summer season (Fig. 6b) can be explained through increased temperature and photosynthetically driven calcite precipitation. The increased summer productivity is verified by phytoplankton counts and chlorophyll $a$ measurements; however, phytoplankton never drops below $10 \%$ of its maximum density (Patceva 2005). This comparably high standing crop can also partly explain the similar summer and winter sedimentation of TOC and TN (Fig. 6c,d). However, higher TP sedimentation in winter (Fig. 6e) is most likely the result of allochthonous material over the winter months, when about $70 \%$ of annual precipitation is occurring. The low corresponding molar ratios of TOC: TP and TN : TP (Fig. 6g,h) indicate as well that a large share of the allochthonous $\mathrm{P}$ input is of inorganic, apatite-bound form (Downing and McCauley 1992).

Compared with trap results, cores provide an averaged picture of sedimentation, both spatially and temporally. Net sedimentation estimates are based on the three OHR sediment cores that have been taken along the north-south axis of Lake Ohrid (Fig. 1). The results for TIC, TOC, and $\mathrm{TN}$ contents are in excellent agreement with four additional cores taken and analyzed in 2005 (Fig. 7), despite the numerous thrusts and folds that have been observed at the lake bottom in a seismic survey (Wagner et al. in press). As a result the three OHR cores can be assumed to give a representative picture of lake sedimentation.

$210 \mathrm{~Pb}$ dating of core OHR02-1 provided an average sediment accumulation of sed $\sim 0.09 \pm 0.02 \mathrm{~cm} \mathrm{yr}^{-1}$. This result is in line with the $0.08 \mathrm{~cm} \mathrm{yr}^{-1}$ reported by Roelofs and Kilham (1983) for cores taken in 1973. Thus $0.09 \mathrm{~cm}$ $\mathrm{yr}^{-1}$ should be reliable, covering at least the topmost $8 \mathrm{~cm}$ $(\sim 100 \mathrm{yr})$ of the core, if we assume that ${ }^{210} \mathrm{~Pb}$ dating is appropriate for the past $\sim 70 \mathrm{yr}(\approx$ three times the half-life of ${ }^{210} \mathrm{~Pb}$ ). Using ${ }^{14} \mathrm{C}$ dating, Roelofs and Kilham (1983) found $0.045 \mathrm{~cm} \mathrm{yr}^{-1}$ for sediment layers beyond 10,000 yr of age, which indicates that no dramatic changes in sed occurred even over long time spans. Gross sedimentation from sediment traps $\sim 1.0 \mathrm{~g} \mathrm{~m}^{-2} \mathrm{~d}^{-1}$ (Fig. 6a) would lead to a sed $\sim 0.07 \mathrm{~cm} \mathrm{yr}^{-1}$, assuming a water content of $\sim 60 \%$ as found in the top $8 \mathrm{~cm}$ of the cores. Total sedimentation (Eq. 1) is $\sim 26 \%$ higher in the cores than for the sediment traps, consistent with $0.02 \mathrm{~cm} \mathrm{yr}^{-1}$ difference in sed. In contrast, individual material sedimentation in the top $2 \mathrm{~cm}$ of the cores was found on average 30\% lower 


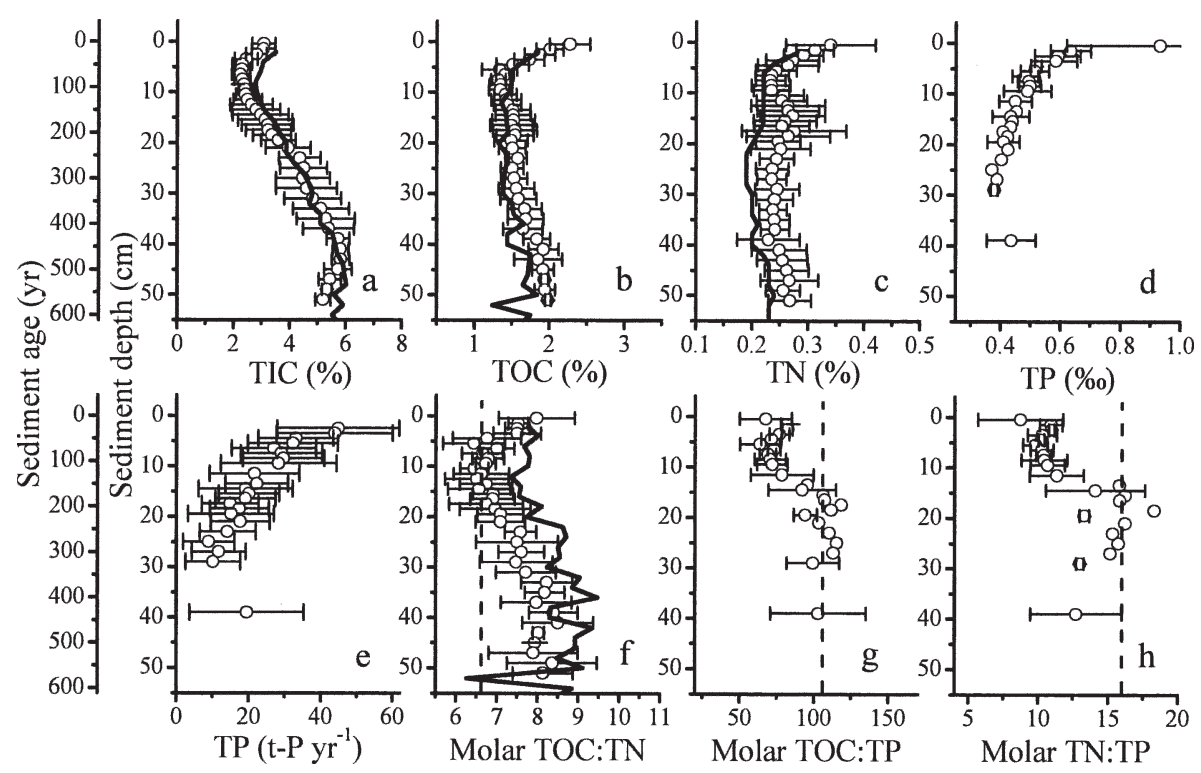

Fig. 7. Results from sediment cores. Circles are mean values of three cores taken in 2002 and 2003 (OHR02-1, OHR03-1, OHR03-2, Fig. 1). Error bars are standard deviations of the three cores, including dating error for (e). Bold lines are mean results from four cores taken and analyzed in 2004 (Lz1083-Lz1086, Fig. 1; Wagner et al. in press). (a) to (d) show relative sediment contents, (e) is $\mathrm{P}$ accumulation, (f) to (h) are molar ratios. Dashed lines in (f) to (h) are Redfield ratio $(\mathrm{C}: \mathrm{N}: \mathrm{P}=106: 16: 1)$. Sediment age is extrapolated from ${ }^{210} \mathrm{~Pb}$ dating.

than in the sediment traps for TIC, TOC, and TN, and $16 \%$ higher for TP. The results imply that - in contrast to TOC and $\mathrm{TN}$ - release of TP is relatively weak during settling and takes place mainly at the sediment (Fig. 6c-e). This is also indicated by the sharp TP decrease within the top sediment layer (Fig. $7 \mathrm{~d}$ ). The $\mathrm{P}$ release during early diagenesis was estimated to be $\sim 32 \mathrm{t} \mathrm{yr}^{-1}$, by comparing sedimentation from $0-2 \mathrm{~cm}$ with $2-4 \mathrm{~cm}$ depth. The $32 \mathrm{t} \mathrm{yr}^{-1}$ represent a maximum estimate, as it also contains a potential eutrophication signal of the past two decades.

Molar TOC: TN : TP ratio stayed almost constant over the past 100-200 $\mathrm{yr}$ (Fig. 7f,g). The abrupt change in TOC:TP and TN:TP at 15-20-cm sediment depth is the result of the increase in TOC and TN with depth of the core (Fig. $7 \mathrm{~b}, \mathrm{c}$ ). This increase might stem from a change in allochthonous organic material input, but cannot be interpreted on the basis of the available data. However, TOC:TP and TN:TP are below Redfield, contrary to expectations for a P-limited lake (Fig. 7g,h). The low ratios can be explained by a significant fraction of nondecomposable, possibly apatite-bound $\mathrm{P}$.

Below $20-\mathrm{cm}$ core depth ( $>220 \mathrm{yr}$ old), the cores show background $\mathrm{P}$ sedimentation of $\sim 66 \mathrm{t} \mathrm{yr}^{-1}$, far higher than estimated current SRP input (Table 4) and therefore mostly consisting of inorganic $\mathrm{P}$. For the organic $\mathrm{P}$ cycle, core data were corrected in Fig. 7e to an estimated natural, bioavailable $\mathrm{P}$ input of $14 \mathrm{t} \mathrm{yr}^{-1}$ for a roughly 10 times smaller population. On the basis of this correction we find a recent gross sedimentation of noninert $\mathrm{P}$ of $\sim 76 \mathrm{t} \mathrm{yr}^{-1}$ in the top $2 \mathrm{~cm}$ of the cores. Below this top layer between 2- and 4-cm sediment depth or $\sim 30 \mathrm{yr}$ before present, when major early diagenetic processes are terminated, recent net $\mathrm{P}$ sedimentation is $\sim 44 \mathrm{t} \mathrm{yr}^{-1}$. During these three decades about $76-44=32 \mathrm{t} \mathrm{yr}^{-1}$ are released to the water column. This $42 \%$ release rate is in the range of observations by Hupfer et al. (1995) and Moosmann et al. (2006). The high background of inorganic P-typical for mountainous, oligotrophic regions - is imported by surface runoff following heavy rain events (Müller et al. 2006) and by dry deposition (Herut et al. 1999).

$P$ dynamics in the water column-Over the period of observation average lake concentrations $\mathrm{TP} \approx 4.6 \pm$ $0.8 \mathrm{mg} \mathrm{m}^{-3}$ and $\mathrm{SRP} \approx 2.1 \pm 0.5 \mathrm{mg} \mathrm{m}^{-3}$ were found. Average concentrations and molar fractions in the euphotic zone of $\mathrm{TN}: \mathrm{TP} \approx 54$ and dissolved inorganic $\mathrm{N}: \mathrm{P} \approx 220$ indicate an oligotrophic, P-limited situation (Guildford and Hecky 2000). It is important to mention that the euphotic zone extends down to $150 \mathrm{~m}$ depth because of the exceptionally high water clarity of the lake (Fig. 2b; Ocevski and Allen 1977; Patceva 2001). Because of the relatively low $\mathrm{P}$ concentrations in Lake Ohrid measurement errors are large, with $41 \%$ and $29 \%$ for TP and SRP, respectively; hence short-term $\mathrm{P}$ content variations cannot be interpreted.

TP and SRP concentrations in the deep hypolimnion below $150 \mathrm{~m}$ are consistently higher than in the euphotic layer above (Fig. 8b,c), indicating SRP release from settling particles despite the aerobic water column, as has been observed by Hayes and Phillips (1958) or more recently by Gächter and Müller (2003) and Moosmann et al. (2006). Indeed, SRP makes up $\sim 60 \%$ of the average difference $\mathrm{TP}_{150-270 \mathrm{~m}}-\mathrm{TP}_{0-150 \mathrm{~m}} \approx 1.7 \mathrm{mg} \mathrm{m}^{-3}$. The role of 

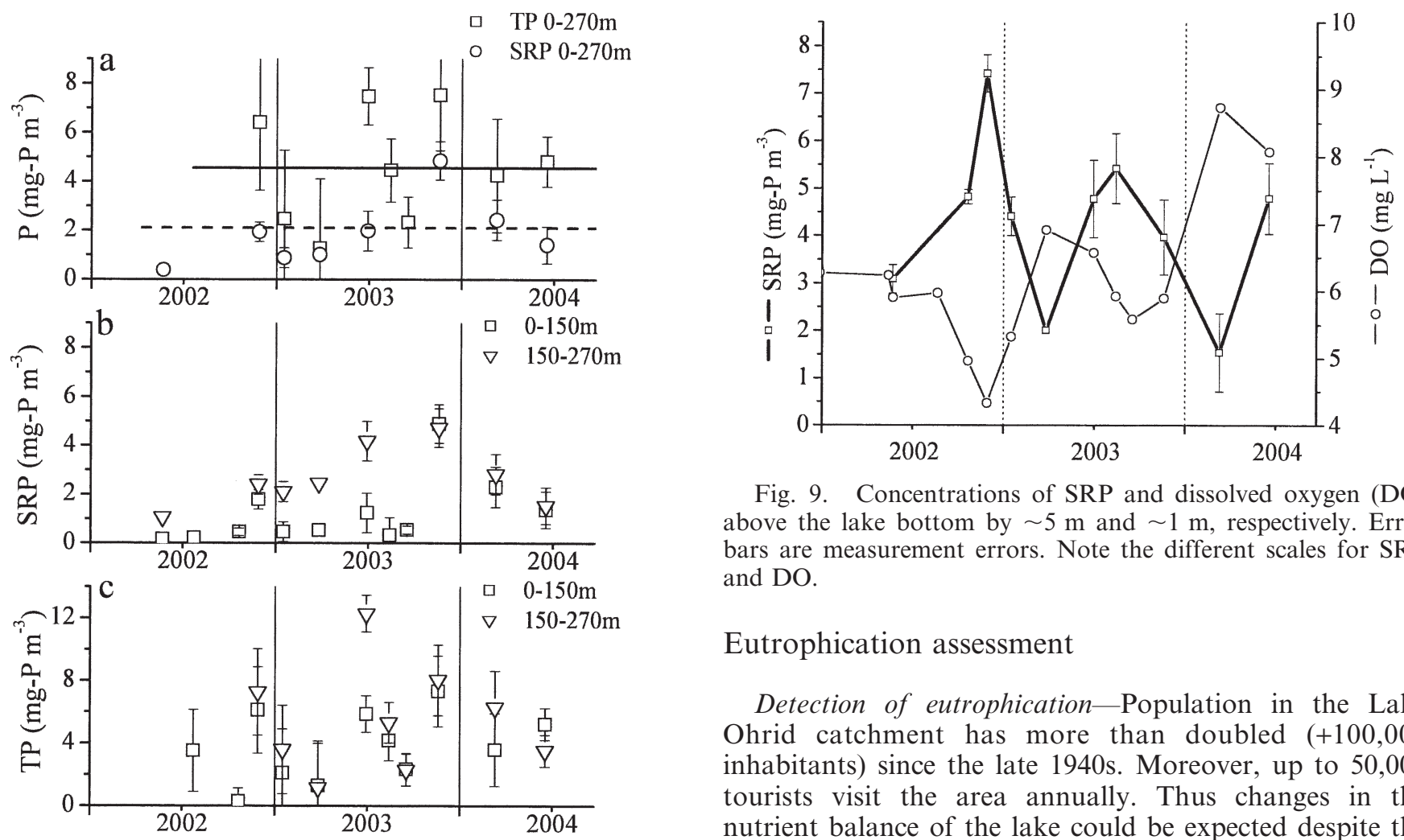

Fig. 9. Concentrations of SRP and dissolved oxygen (DO) above the lake bottom by $\sim 5 \mathrm{~m}$ and $\sim 1 \mathrm{~m}$, respectively. Error bars are measurement errors. Note the different scales for SRP and DO.

\section{Eutrophication assessment}

Detection of eutrophication-Population in the Lake Ohrid catchment has more than doubled $(+100,000$ inhabitants) since the late 1940s. Moreover, up to 50,000 tourists visit the area annually. Thus changes in the nutrient balance of the lake could be expected despite the installation of a limited sewer and treatment system in Macedonia in the 1970s and its improvement since 1995.

Concurrent increase in TOC, TN, and TP in the top sediment (Fig. 7b-d) is a clear sign of ongoing eutrophication (Schelske and Hodell 1995). The increase can be split into a period of slow eutrophication, which started about $150-200 \mathrm{yr}$ ago, and an accelerated phase over the past $\sim 50 \mathrm{yr}$ (Fig. 7e).

mineralization and consequent SRP release is evidenced by parallel maximum SRP and minimum DO concentrations close to the lake bottom (Fig. 9). Annual hypolimnetic SRP increase can be estimated from observations to $\sim 21 \mathrm{t} \mathrm{yr}^{-1}$ and $\sim 28 \mathrm{t} \mathrm{yr}^{-1}$ for the years 2002 and 2003, respectively (Fig. 8b).

Overall phosphorus budget - The overall budget (Table 4) is consistent regarding gross sedimentation (top of sediment cores vs. sediment traps) and $\mathrm{P}$ release during early diagenesis (sediment cores vs. SRP in water column).

Adding up the $\mathrm{P}$ net sedimentation and the $\mathrm{P}$ outflow amounts to an annual input of bioavailable phosphorus of $44+3=47 \mathrm{t} \mathrm{yr}^{-1}$. The difference of $\sim 20 \mathrm{t} \mathrm{yr}^{-1}$ from the measured SRP input in Table 4 could be explained by "diffusive" point sources. According to Foy et al. (1995) a P load of $20 \mathrm{t} \mathrm{yr}^{-1}$ is equivalent to the urban $\mathrm{P}$ discharge of about 20,000 people. In 1995 the households of 9,000 people living in villages directly at the lake shore and up to 100,000 people throughout the catchment were without connection to any sewage treatment. The same is valid for several hotels and campsites. Moreover, sewage pumps were reported to overflow regularly during heavy rainstorms. Thus $20 \mathrm{t} \mathrm{yr}^{-1}$ of additional $\mathrm{P}$ sources seem more than plausible.

Timescales - On the basis of $\mathrm{P}$ monitoring and the net sedimentation of organic and bioavailable $\mathrm{P}$ in Table 4, a linear P model can be set up according to Eq. 2. It was assumed that the current TP concentration of $\sim 4.6 \mathrm{mg} \mathrm{m}^{-3}$ is near steady state. On the basis of the parameters $\beta(\approx 0.84)$ and $\sigma\left(\approx 0.18 \mathrm{yr}^{-1}\right)$ derived from the observations, $\tau_{\mathrm{P}}{ }^{*} \approx 5.3 \mathrm{yr}$ was found, which is the average time that bioavailable $\mathrm{P}$ will remain in the water column before being buried in the sediment or leaving via outflow. After an increase in $\mathrm{P}$ input, new equilibrium concentration will be reached to $95 \%$ after $3 \times \tau_{\mathrm{P}}{ }^{*} \approx 16 \mathrm{yr}$ and will thus lag behind significantly.

Having estimated historic $\mathrm{P}$ loads of $\sim 14 \mathrm{t} \mathrm{yr}^{-1}$ (see $P$ outputs above), Eq. 2 can be used to calculate corresponding $P$ concentrations. Using current parameters $\beta$ and $\sigma$ we find an equilibrium TP concentration of $\sim 1.3 \mathrm{mg} \mathrm{m}^{-3}, 3.5$ times less than today.

Answers to questions ( $i$ ) and (ii) - On the basis of the assessment above, the two first questions can be answered:

(i) Lake Ohrid is clearly in the process of eutrophication, given the sediment records. On the basis of a linear model the $\mathrm{P}$ concentration in the lake may have 
Table 6. Simulated scenarios and their effects on Lake Ohrid.

\begin{tabular}{|c|c|c|c|c|c|c|}
\hline \multicolumn{2}{|c|}{ Scenario } & \multicolumn{5}{|c|}{ Results } \\
\hline $\begin{array}{c}\text { Global warming } \\
\left({ }^{\circ} \mathrm{C} \mathrm{yr}^{-1}\right)\end{array}$ & $\begin{array}{c}\text { P load } \\
(\% \text { of status quo })\end{array}$ & $\begin{array}{l}Z_{\text {mix* }}^{*} \\
\text { (m) }\end{array}$ & $\begin{array}{c}K_{z} \text { at } 200 \mathrm{~m} \mathrm{depth}^{\dagger} \\
\left(\mathrm{cm}_{2} \mathrm{~s}^{-1}\right)\end{array}$ & $\begin{array}{c}z \text { above which } \\
\text { DO }>6.2 \mathrm{mg} \mathrm{L}^{-1 \dagger}+ \\
(\mathrm{m})\end{array}$ & $\begin{array}{l}\text { Average } \mathrm{TP}^{\dagger} \S \\
\left(\mathrm{mg}-\mathrm{P} \mathrm{m}^{-3}\right)\end{array}$ & $\begin{array}{c}\text { Gross primary } \\
\text { production }{ }^{\dagger} \\
(\% \text { of status quo })\end{array}$ \\
\hline \multirow[t]{3}{*}{ 0\| } & 50 & 289 & 2.6 & 289 & $1.0 / 2.2$ & 70 \\
\hline & $100 \|$ & 289 & 2.2 & 288 & $1.8 / 4.6$ & 100 \\
\hline & 200 & 204 & 1.5 & 198 & $5.6 / 13.9$ & 123 \\
\hline \multirow[t]{3}{*}{0.01} & 50 & 289 & 2.1 & 289 & $1.0 / 2.5$ & 71 \\
\hline & 100 & 247 & 1.8 & 257 & $1.8 / 5.2$ & 101 \\
\hline & 200 & 97 & 1.1 & 102 & $4.6 / 17.3$ & 129 \\
\hline \multirow[t]{3}{*}{0.02} & 50 & 125 & 1.3 & 289 & $1.0 / 2.9$ & 71 \\
\hline & 100 & 89 & 1.1 & 114 & $1.7 / 7.1$ & 99 \\
\hline & 200 & 76 & 0.8 & 84 & $3.5 / 21$ & 130 \\
\hline \multirow[t]{3}{*}{0.04} & 50 & 71 & 0.7 & 92 & $0.9 / 5.4$ & 67 \\
\hline & 100 & 64 & 0.6 & 76 & $1.5 / 11.3$ & 94 \\
\hline & 200 & 58 & 0.5 & 69 & $2.7 / 23.4$ & 129 \\
\hline
\end{tabular}

\footnotetext{
* Maximum convective mixing depth in 2067.

$\dagger$ Averaged from 2053-2067.

\$ $6.2 \mathrm{mg} \mathrm{L}^{-1}$ is the minimal observed (2001-2004) mean DO level below $200 \mathrm{~m}$ depth.

${ }^{\S}$ First value: $0-50 \mathrm{~m}$; second value: $0-289 \mathrm{~m}$.

" Bold numbers are status quo.
}

increased by a factor of $\sim 3.5$, from historic $\sim 1.3 \mathrm{mg} \mathrm{m}^{-3}$ to current $\sim 4.6 \mathrm{mg} \mathrm{m}^{-3}$. The most probable reason for eutrophication is the increase in domestic sources due to growing population.

(ii) Different timescales are important. Eutrophication is relatively slow but ongoing since $\sim 150$ to $200 \mathrm{yr}$ ago. Since the late 1940s its speed seems to have accelerated. Average $\mathrm{P}$ residence time is $\sim 5.3 \mathrm{yr}$. As a result it takes many years before increased $\mathrm{P}$ inputs can be detected.

\section{Definition of sustainable phosphorus load}

Scenario development - Given its importance for the endemic fauna of Lake Ohrid, hypolimnetic DO is applied for the definition of sustainable P load. However, it is unknown which level of DO might be critical for the endemic species of Lake Ohrid. During the period of observation average DO below $200 \mathrm{~m}$, referred to as $\mathrm{DO}_{\text {hypo }}$ in the following, never dropped below $\sim 6.2 \mathrm{mg} \mathrm{L}^{-1}$ (Fig. 3d), which seems to be sufficient for profundal bottom fauna and deep-living fish species (S. Trajanovski and Z. Spirkovski pers. comm.). Directly above the lake bottom DO levels down to $4.3 \mathrm{mg} \mathrm{L}^{-1}$ have occurred over short time periods (Fig. 9). However, the following analysis concentrates on $\mathrm{DO}_{\text {hypo }}$ because the phenomenon concerns only a small volume of the lake.

$\mathrm{DO}_{\text {hypo }}$ in Lake Ohrid has been shown to be sensitive to changes in lake stratification because of global warming (Matzinger et al. 2006b). Thus several scenarios were used for the next decades, from no warming to the expected $0.04^{\circ} \mathrm{C} \mathrm{yr}^{-1}$ increase in air temperatures for the Balkan Peninsula (Table 6), on the basis of a two- to threefold increase in atmospheric $\mathrm{CO}_{2}$ level over the next century (Giorgi et al. 2004). Following model results by Mortsch and Quinn (1996) and observations by Livingstone and Lotter (1998), increase in air temperature was directly transferred to the surface of Lake Ohrid and its tributaries. Global warming is expected to affect lake mixing through enhanced stratification during the warming process and, in contrast, stronger convective mixing because of increasing thermal expansivity with water temperature (Matzinger et al. 2006b). Reduced vertical mixing will lead to a decrease in upward transport of SRP and thus lake productivity. Consequently $\mathrm{DO}_{\text {hypo }}$ would be enhanced by lower lake productivity and sedimentation of organic matter but limited by reduced downward flux of DO. Finally, higher temperatures will positively affect biological processes such as algal growth and decomposition of organic matter but reduce DO solubility in water.

Unlike global warming, lake eutrophication can be controlled by local measures. Thus both increased as well as decreased anthropogenic P loads, relative to the current situation, are considered in separate scenarios (Table 6). Changes in $\mathrm{P}$ input are expected to affect the entire biogeochemical cycle and thus DO production in the trophogenic layer as well as DO consumption at the lake bottom. Moreover, increased salt transfer to the hypolimnion is anticipated from eutrophication via mineralization of settled organic matter and calcite. This salt transfer was assumed to be changing linearly with gross $\mathrm{P}$ sedimentation.

It is not clear, a priori, which of the competing processes above dominate under different boundary conditions. To test their relative importance the above scenarios are discussed in the following, on the basis of the results of a coupled physical, biogeochemical lake model, calibrated to observations (Fig. 3; Web Appendix 1). The term "status quo" is used to refer to current $\mathrm{P}$ loads and no warming, although an atmospheric warming of $\sim 0.006^{\circ} \mathrm{C} \mathrm{yr}^{-1}$ has been observed over the past decades (IPCC 2001). 

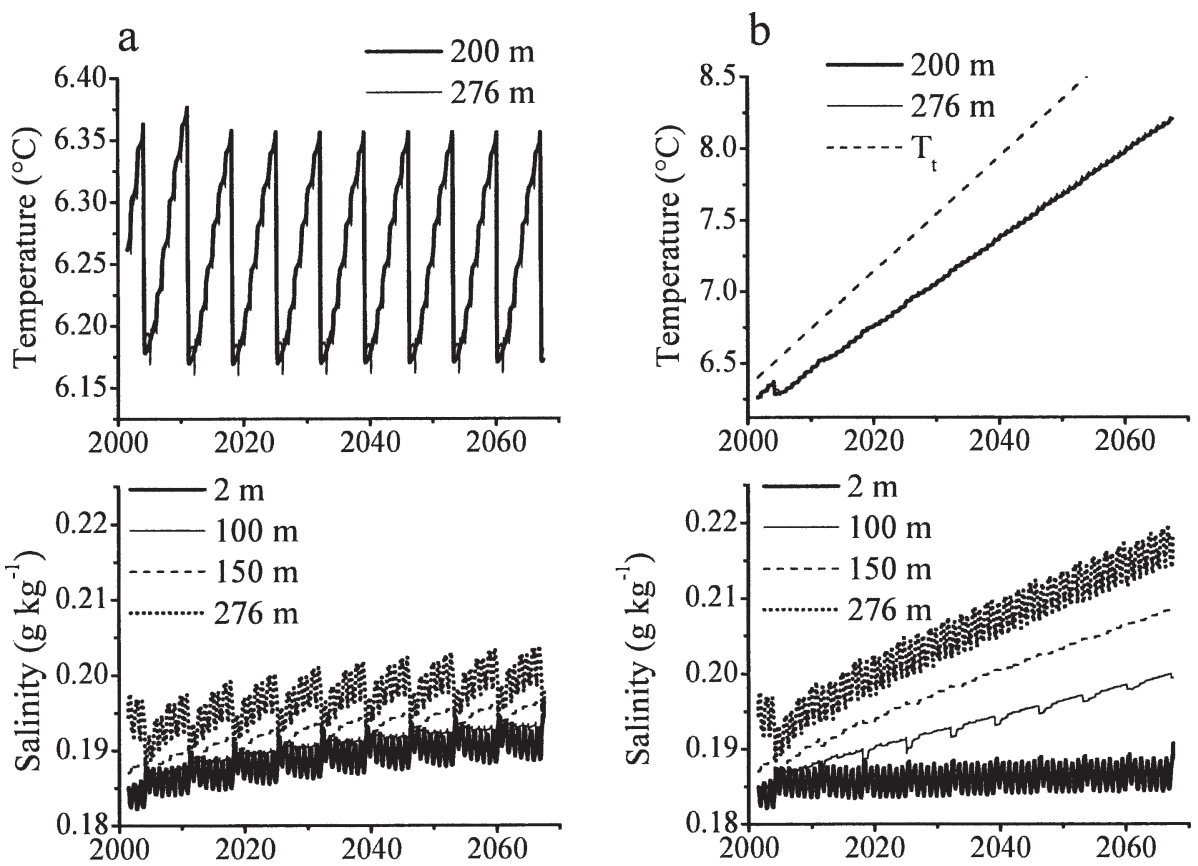

Fig. 10. Bottom temperature and salinity simulated by $k-\varepsilon$ model for different depths (see legend). (a) Status quo. (b) Temperature increase of $T_{t}=0.04^{\circ} \mathrm{C} \mathrm{yr}^{-1}$ and status quo for $\mathrm{P}$ load; $T_{t}$ is shown for comparison with simulated in situ temperatures.

Vertical mixing and stratification-Vertical exchange through occasional complete overturns and the exchange between the annually mixed layer-stretching as deep as $200 \mathrm{~m}$ - with the lower, stratified hypolimnion are crucial for biogeochemical cycling. Vertical mixing at the $200-\mathrm{m}$ boundary is about one order of magnitude larger from December to March (diffusion coefficient $K_{z \text { win }} \approx$ $\left.2.5 \mathrm{~cm}^{2} \mathrm{~s}^{-1}\right)$ compared to strong stratification from April to November $\left(K_{z \text {,sum }} \approx 0.25 \mathrm{~cm}^{2} \mathrm{~s}^{-1}\right)$, in agreement with indirect measurements by Matzinger et al. (2006b). Under status quo complete overturn is occurring roughly once every $7 \mathrm{yr}$ (Hadzisce 1966; Matzinger et al. 2006b). Consequently the most probable situation was simulated with regular complete overturns at 7 -yr intervals on the basis of observed meteorological forcing (Fig. 10).

The vertical mixing pattern changes significantly for the different scenarios in Table 6. At an atmospheric warming of $T_{t} \approx 0.04^{\circ} \mathrm{C} \mathrm{yr}^{-1}$, temperature and salinity gradients increase with time, rendering stratification more and more stable (Fig. 10b). As a result the water body below $\sim 64 \mathrm{~m}$ is basically secluded from the regularly mixed top layer after $60 \mathrm{yr}$ of simulation, even in comparably cool winters. The exchange between this upper layer and the hypolimnion -important for transport of nutrients and DO-is on average more than three times lower compared with the status quo (Table 6). It is interesting that hypolimnetic mixing does not decrease linearly with increasing atmospheric warming rates $T_{t}$. The strongest change occurs between $T_{t}=0.01^{\circ} \mathrm{C}$ and $0.02^{\circ} \mathrm{C} \mathrm{yr}^{-1}$, where $K_{z}$ is reduced by $50 \%$ (Table 6 ) and maximal convective mixing depth decreases from $\sim 250 \mathrm{~m}$ to merely $\sim 90 \mathrm{~m}$. Up to a certain warming rate, obviously between $0.01^{\circ} \mathrm{C}$ and $0.02^{\circ} \mathrm{C} \mathrm{yr}^{-1}$ for Lake Ohrid, bottom water temperature can cope with the pace through geothermal heating and vertical exchange. Once $T_{t}$ goes beyond that threshold, bottom temperature lags behind, leading to an increase in stratification with time. Thus the warming rate rather than the absolute temperature increase is crucial for the extent of deep water isolation.

Under predicted $T_{t}$, eutrophication is of secondary importance for vertical mixing. However, at $T_{t}=0.01^{\circ} \mathrm{C}$ $\mathrm{yr}^{-1}$, eutrophication-induced salt input from mineralization would lead to a deepwater isolation of similar extent as

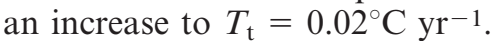

In situ biogeochemical processes-As for the physical parameters, an excellent agreement of the model was found with observed $\mathrm{P}$ and TOC balances, primary productivity, and DO concentrations (Fig. 3; Web Appendix 1). During periods without complete overturn $\mathrm{DO}_{\text {hypo }}$ continuously decreases, whereas total dissolved phosphorus (TDP) is increasing because of release during mineralization (Fig. 11a,b). After complete overturn both DO and TDP are distributed almost homogeneously throughout the water column. As a result productivity in the trophogenic layer increases, which consequently leads to high sedimentation of organic particles and consumption of DO in the hypolimnion. It is interesting to note that raised primary productivity after complete overturns can well be seen in simulated $\mathrm{DO}_{\text {hypo }}$, sedimentation of organic matter, or zooplankton biomass (Fig. 11a,d). However, TP concentration shows but minor fluctuations and phytoplankton abundance is not a reliable indicator at all (Fig. 11b,c). 


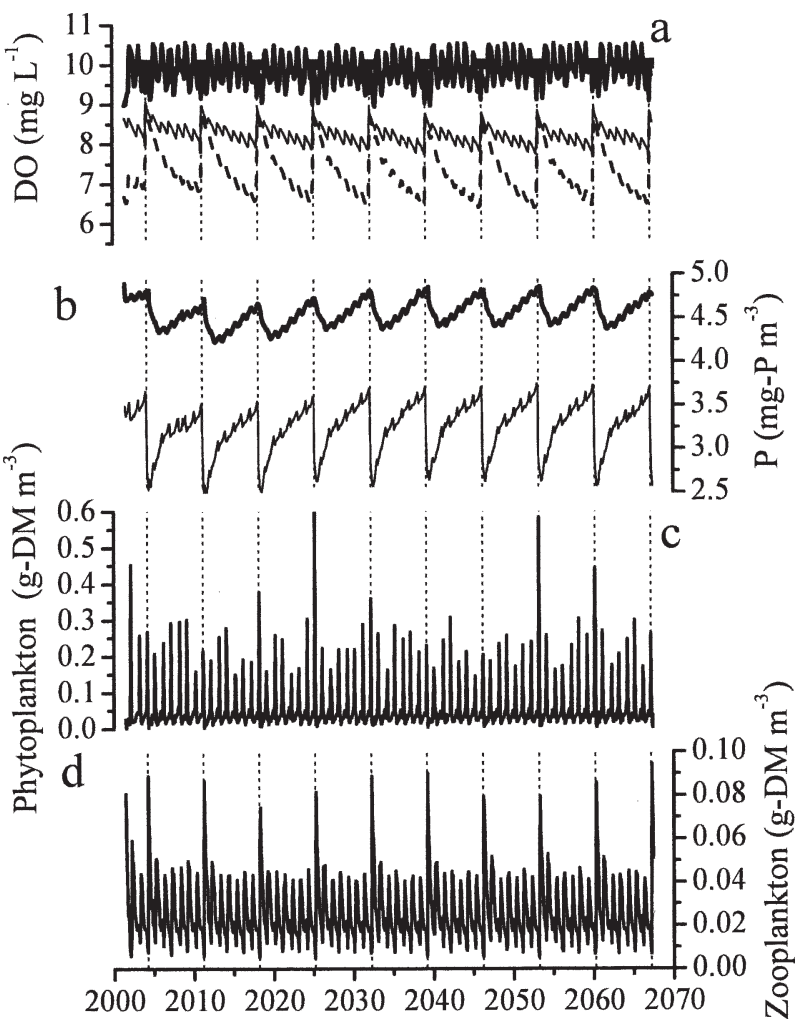

Fig. 11. Simulation results for status quo over a 66-yr period. (a) Averaged DO concentration, 0-50 m (thick line), 50 $200 \mathrm{~m}$ (thin line), 200-289 m (dashed line). (b) Averaged TP concentration (thick line) and total dissolved phosphorus (thin line). (c and d) Plankton biomass. Dotted, vertical lines indicate years of complete overturn.

The results of the different scenarios are shown in Table 6 , on the basis of average simulation results from 2053-2067. Whereas the influence of P load on average lake TP is straightforward, the simulated TP increase with global warming is less obvious. It was found to be mainly the result of reduced mixing (Table 6), which leads to TDP accumulation in the hypolimnion. Despite this $\mathrm{P}$ accumulation, TDP is depleted in the top $50 \mathrm{~m}$ with increasing temperature, because of reduced winter P flux from below (Table 6). As a result smaller primary productivity would be expected in P-limited Lake Ohrid because of global warming. However, Table 6 shows that primary productivity almost exclusively depends on the $\mathrm{P}$ load, irrespective of the extent of warming. The reason lies in the temperature dependence of phytoplankton growth and microbiological $P$ recycling, which in the case of Lake Ohrid are almost exactly compensating the effect of reduced mixing.

$\mathrm{DO}_{\text {hypo }}$, the goal variable for the endemic bottom fauna, is particularly interesting, as it is influenced by net system productivity via settling organic matter, as well as by vertical exchange through mixing. Thus both $\mathrm{P}$ loads and global warming are expected to be key boundary conditions. Indeed, the depth $z_{\mathrm{DO}}>$ Doref, above which $\mathrm{DO}$ is higher than $\mathrm{DO}_{\text {ref }}=6.2 \mathrm{mg} \mathrm{L}^{-1}$, was found to decrease with increasing extent of both eutrophication and warming (Table 6). However, $z_{\text {DO }>\text { DOref }}$ does not decrease linearly but switches between two main states: A first, where basically the whole lake is above $\mathrm{DO}_{\text {ref }}\left(z_{\mathrm{DO}}>\right.$ DOref $=250$ $289 \mathrm{~m}$ ) and a second, where only the top third of the water

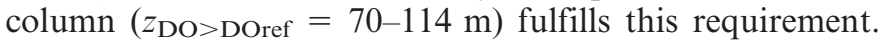
Under status quo P load, DO switches states between $T_{t}$ of $0.01{ }^{\circ} \mathrm{C} \mathrm{yr}^{-1}$ and $0.02^{\circ} \mathrm{C} \mathrm{yr}^{-1}$. However, a similar switch in DO occurs between $T_{t}$ of $0.02^{\circ} \mathrm{C} \mathrm{yr}^{-1}$ and $0.04^{\circ} \mathrm{C} \mathrm{yr}^{1}$ for a $50 \%$ reduction of $\mathrm{P}$ loads but already at 0 or $0.01^{\circ} \mathrm{C} \mathrm{yr}-1$ for doubled $\mathrm{P}$ loads. The worst-case scenario-an air temperature increase of $0.04^{\circ} \mathrm{C} \mathrm{yr}^{-1}$ coupled with a doubling of anthropogenic $\mathrm{P}$ input-would lead to DO < $\mathrm{DO}_{\text {ref }}$ below $69-\mathrm{m}$ depth and practically anoxic conditions below $110 \mathrm{~m}$. In that case the sediment area for which DO $>\mathrm{DO}_{\text {ref }}$ would be reduced by $\sim 280 \mathrm{~km}^{2}$ or $80 \%$. The dependency of DO availability on external P loads and global atmospheric warming is summarized in Fig. 12. The DO isolines are clearly not equidistant, which further underlines nonlinearity with forcing.

From a lake management point of view the findings imply that P loads must be adapted to the extent of global warming to maintain oxic conditions in the hypolimnion. If air warming exceeds $0.01^{\circ} \mathrm{C} \mathrm{yr}^{-1}$ over the next decades, a reduction in anthropogenic $\mathrm{P}$ load is necessary to keep $\mathrm{DO}_{\text {hypo }}$ above the observed minimum of $6.2 \mathrm{mg} \mathrm{L}^{-1}$. However, with predicted $T_{t}=0.04^{\circ} \mathrm{C} \mathrm{yr}^{-1}$, anthropogenic $\mathrm{P}$ load has to be reduced by at least $50 \%$ to find $\mathrm{DO}_{\text {hypo }}$ just around the minimum observed bottom concentration of $\sim 4 \mathrm{mg} \mathrm{L}^{-1}$ after $\sim 60 \mathrm{yr}$ (Fig. 12).

Another important aspect, not shown in Fig. 12, is the temporal dynamics of $\mathrm{DO}_{\text {hypo }}$. While $\mathrm{DO}_{\text {hypo }}$ approaches equilibrium under status quo and for moderate warming scenarios, it simply decreases for $T_{t}=0.04^{\circ} \mathrm{C} \mathrm{yr}^{-1}$ (Fig. 13a). By reducing the P load only the speed of this decrease can be influenced (Fig. 13b); however, increasing hypolimnion stratification (Fig. 10b) causes anoxia eventually. In the long run anoxia can only be prevented if global warming remains below the projected rate (Fig. 13b).

Answer to question (iii) - Lake Ohrid is highly sensitive to increased $\mathrm{P}$ loads, as well as global warming. In particular $\mathrm{DO}_{\text {hypo }}$ is reduced both by increased productivity from higher $\mathrm{P}$ loads as well as reduced mixing due to global warming. As a result, sustainable $\mathrm{P}$ load cannot be defined by a constant but has to be expressed as a function of global warming. A reduction of current anthropogenic $\mathrm{P}$ loads by $50 \%$ must be achieved to keep most of the lake above $4 \mathrm{mg} \mathrm{L}^{-1}$ for the next decades.

\section{Discussion}

Lake Ohrid - The analysis of Lake Ohrid nutrient balance clearly points to a eutrophication process, which has led to more than a threefold increase in average $\mathrm{P}$ concentration over the past century. Although Lake Ohrid is a slowreacting ( $\mathrm{P}$ residence time $\sim 5 \mathrm{yr}$ ) and oligotrophic system, the ongoing eutrophication was traced and quantified with low-cost monitoring, thanks to a combination of information on river inputs, lake concentrations, sediment cores, and population development in the catchment. 


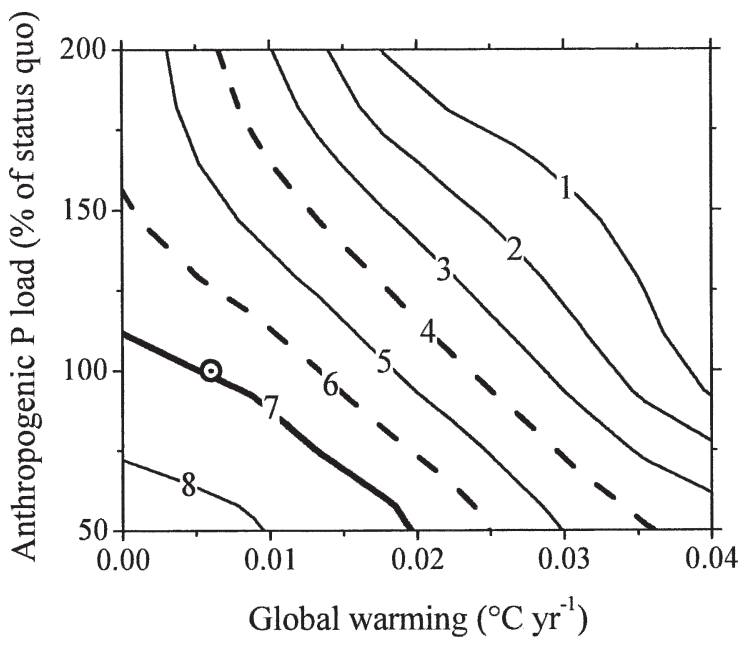

Fig. 12. Dependence of DO availability on anthropogenic P load and global (atmospheric) warming. DO [mg L $\left.{ }^{-1}\right]$ values (numbers in plot) are volume-weighted averages below 200-m depth for the simulated period 2053-2067. Bold line indicates current mean DO $\left(\sim 7 \mathrm{mg} \mathrm{L}^{-1}\right)$, dashed lines are minimal observed mean DO $\left(\sim 6 \mathrm{mg} \mathrm{L}^{-1}\right)$ and minimal overall DO, measured directly over lake bottom $\left(\sim 4 \mathrm{mg} \mathrm{L}^{-1}\right)$, all from 2001-2004. Circle represents current situation with observed temperature increase $\sim 0.006^{\circ} \mathrm{C} \mathrm{yr}^{-1}$ from the past decades (IPCC 2001).

On the basis of simulation results, increase in $\mathrm{P}$ loads to Lake Ohrid leads to higher lake productivity and consequently higher sediment fluxes and mineralization. As a secondary effect water column stratification is stabilized because of an increase in salt transfer to the hypolimnion by mineralization. However, mixing is reduced to a much larger extent by anticipated global warming, since the temperature of the deep water lags behind, increasing the density difference to the surface layer.

Both processes - higher mineralization at the sediment and reduced mixing of the water column-lead to a decrease in DO in the deep water. If air temperatures increase by $4^{\circ} \mathrm{C}$ over the next century as predicted, current anthropogenic $\mathrm{P}$ load would have to be reduced by at least $50 \%$ to maintain sufficient oxygen conditions for the endemic bottom fauna for the next decades.

Lake management is challenged to reduce $\mathrm{P}$ loads to Lake Ohrid and keep them on a low level, as global warming seems to be already occurring and is likely to accelerate. Positive steps in that direction have been taken in Macedonia over the past $5 \mathrm{yr}$ by extending the sewerage system and limiting the $\mathrm{P}$ content in washing agents $(\mathrm{G}$. Traub pers. comm.).

Timescales of expected changes are relatively long, on the order of decades: e.g., even at worst-case scenario of

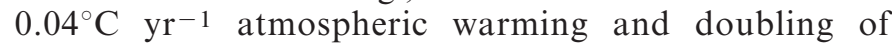
anthropogenic P input, $\mathrm{P}$ concentration in Lake Ohrid would increase at a rate of only $0.4 \mathrm{mg} \mathrm{m}^{-3} \mathrm{yr}^{-1}$. As a result long-term, regular monitoring of basic parameters is a necessity to track such slow changes and plan or evaluate protection measures. Still, $\mathrm{P}$ makes a sensible monitoring parameter as it reacts primarily to higher $\mathrm{P}$ loads. Temperature $(T)$, on the other hand, allows the
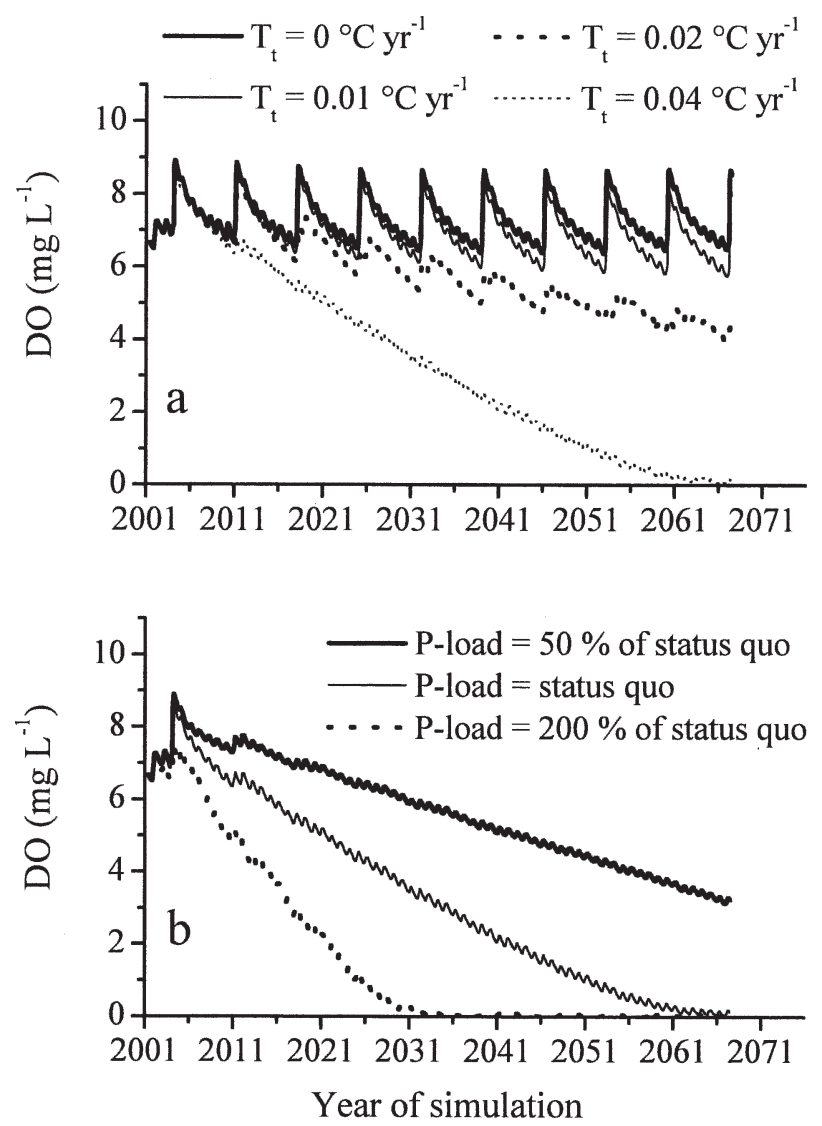

Fig. 13. Simulated hypolimnetic DO (200-289 m) versus time. (a) Global warming scenarios at status quo $\mathrm{P}$ load. (b) Different $\mathrm{P}$ loads with $0.04^{\circ} \mathrm{C} \mathrm{yr}^{-1}$ atmospheric warming.

assessment of the effect of global warming both in terms of absolute $T$ as well as the potential isolation of deep layers. Finally DO is the most complete parameter, as it is most sensitive to both global warming and higher $\mathrm{P}$ input. For Lake Ohrid a long-term monitoring of the three parameters DO, P, and $T$ would allow detection of changes as well as the evaluation of their main causes. While the monitoring of those "simple" parameters is suggested, one should not forget that the reaction of the endemic species, the main treasure of this unique lake, cannot be anticipated and thus their observation should not be neglected.

General implications - While local human pressures may differ, global atmospheric warming would affect most deep lakes by reducing vertical exchange. Deepwater isolation would be expressed most severely in lakes without alternative deepwater renewal, such as turbidity-driven, plunging rivers. Regarding biogeochemical cycling we found that lakes are most sensitive to the rate of warming via vertical mixing, whereas higher temperature showed only secondary effects via biological processes. This phenomenon is very important when discussing temporal stability of the ancient lakes of Table 1 . These lakes have certainly experienced warmer as well as cooler periods than today over their long history; however, predicted global warming rates for the next century may be unprecedented regarding the past million years (Bintanja et al. 2005). 
Many special lakes, such as the ones in Table 1, are equally clean as Lake Ohrid and no urgent eutrophication control measures seem necessary. Nevertheless our analysis shows that it is important to react in time, (1) when dealing with slow-reacting systems and (2) because anticipated global atmospheric changes will amplify effects of eutrophication. The presented analysis is a first important step to assess this interaction. It is suggested that similar monitoring programs be established for other precious ancient lakes.

\section{References}

Beeton, A. M. 2002. Large freshwater lakes: Present state, trends and future. Environ. Conserv. 29: 21-38.

Bintanja, R., R. S. W. van de Wal, and J. Oerlemans. 2005. Modelled atmospheric temperatures and global sea levels over the past million years. Nature 437: 125-128. [doi: 10.1038/ nature03975].

Bootsma, H. A., And E. Hecky. 1993. Conservation of the African Great Lakes: A limnological perspective. Conserv. Biol. 7: 644-656.

, AND - 2003. A comparative introduction to the biology and limnology of the African Great Lakes. J. Great Lakes Res. 29: 3-18.

DEW. 1996. German standard methods for water analysis. V. II. VCH. [In German.]

Downing, J. A., And E. McCauley. 1992. The nitrogenphosphorus relationship in lakes. Limnol. Oceanogr. 37: 936-945.

Eftimi, R., And J. Zoto. 1997. Isotope study of the connection of Ohrid and Prespa lakes. Proceedings of International Symposium Towards Integrated Conservation and Sustainable Development of Transboundary Macro and Micro Prespa Lakes. PPNEA, ILAR Typography, Tirana, Albania: $32-37$.

Foy, R. H., R. V. Smith, C. Jordan, and S. D. Lennox. 1995. Upward trend in soluble phosphorus loadings to Lough Neagh despite phosphorus reduction at sewage-treatment works. Water Res. 29: 1051-1063.

Gächter, R., AND B. Müller. 2003. Why the phosphorus retention of lakes does not necessarily depend on the oxygen supply to their sediment surface. Limnol. Oceanogr. 48: 929-933.

, S. M. Steingruber, M. Reinhardt, And B. Wehrli. 2004. Nutrient transfer from soil to surface waters: Differences between nitrate and phosphate. Aquat. Sci. 66: 117-122.

Gilbert, J. J., And S. Hadzisce. 1984. Taxonomic notes on the shallow-water endemic sponges of Lake Ohrid, Yugoslavia, with a description of two new species and a redescription of Spongilla stankovici. Arch. Hydrobiol. 99: 331-339.

Giorgi, F., X. Bi, AND J. PAL. 2004. Mean, interannual variability and trends in a regional climate change experiment over Europe. II: Climate change scenarios (2071-2100). Clim. Dynam. 23: 839-858. [doi: 10.1007/s00382-004-0467-0].

Goldman, C. R., J. J. Elser, R. C. Richards, J. E. Reuter, J. C. Priscu, AND A. L. Levin. 1996. Thermal stratification, nutrient dynamics, and phytoplankton productivity during the onset of spring phytoplankton growth in Lake Baikal, Russia. Hydrobiologia 331: 9-24.

Goudsmit, G.-H., H. Burchard, F. Peeters, and A. Wüest. 2002. Application of $\mathrm{k}-\varepsilon$ turbulence models to enclosed basins: The role of internal seiches. J. Geophys. Res. 107: 3230. [doi: 10.1029/2001JC000954].
Grove, M. J., P. A. Baker, S. L. Cross, C. A. Rigsby, and G. O. SEltzer. 2003. Application of strontium isotopes to understanding the hydrology and paleohydrology of the Altiplano, Bolivia-Peru. Palaeogeogr. Palaeocl. 194: 281-297.

GuildFord, S. J., AND R. E. Hecky. 2000. Total nitrogen, total phosphorus, and nutrient limitation in lakes and oceans: Is there a common relationship? Limnol. Oceanogr. 45: 1213-1223.

GuseskA, D. 2003. Comparative morphological and ecological characterization of Calanoida and Cyclopoida (Crustacea: Copepoda) from the pelagic zone of Lake Ohrid Ph.D. thesis, University "Sv. Kiril i Metodij". [In Macedonian.]

Hadzisce, S. D. 1966. The mixo-phenomenon of Lake Ohrid in the course of the years 1941/42-1964/65. Proc. Int. Assoc. Theor. Appl. Limnol. 16: 134-138. [In German.]

Hakanson, L., And M. Jansson. 1983. Principles of lake sedimentology. Springer-Verlag.

Hayes, F. R., And J. E. Phillips. 1958. Lake water and sediment-IV. Radiophosphorus equilibrium with mud, plants, and bacteria under oxidized and reduced conditions. Limnol. Oceanogr. 3: 459-475.

Herut, B., M. D. Krom, G. Pan, and R. Mortimer. 1999. Atmospheric input of nitrogen and phosphorus to the southeast Mediterranean: Sources, fluxes, and possible impact. Limnol. Oceanogr. 44: 1683-1692.

Hupfer, M., R. Gächter, and R. Giovanoli. 1995. Transformation of phosphorus species in settling seston and during early sediment diagenesis. Aquat. Sci. 57: 305-324.

IPCC. 2001. Climate change 2001: Synthesis report-contributions of working groups I, II, and III to the IPCC third assessment report.

Ivanova, N. 1974. The influence of the diversion of River Sateska into Lake Ohrid and the temporary regulating construction in Struga upon the oscillations of Lake Ohrid. Proceedings of the Symposium on the Problems of the Regulation of Lake Ohrid. Macedonian Academy of Science and Arts, Skopje: 219-232. [In Macedonian.]

Järvinen, M., K. Salonen, J. Sarvala, K. Vuorio, and A. VIRTANEN. 1999. The stoichiometry of particulate nutrients in Lake Tanganyika-implications for nutrient limitation of phytoplankton. Hydrobiologia 407: 81-88.

Jerkovic, L. 1972. L'ultrastructure des frustules de quelques espèces endemiques des Diatomées de la Yougoslavie. Arch. Hydrobiol.Suppl. 41: 1-10.

Kelts, K., U. Briegel, K. Ghilardi, and K. Hsü. 1986. The limnogeology-ETH coring system. Schweiz. Z. Hydrolog. 48: $104-115$.

KenK, R. 1978. The Planarians (Turbellaria: Tricladida Paludicola) of Lake Ohrid in Macedonia. Smithsonian Contributions to Zoology. Nr. 280. 56 pp.

Livingstone, D. M., And A. F. LotTer. 1998. The relationship between air and water temperatures in lakes of the Swiss Plateau: A case study with paleolimnological implications. J. Paleolimnol. 19: 181-198.

Markaki, Z., K. Oikonomou, M. Kocak, G. Kouvarakis, A. Chaniotaki, N. Kubilay, and N. Mihalopoulos. 2003. Atmospheric deposition of inorganic phosphorus in the Levantine Basin, eastern Mediterranean: Spatial and temporal variability and its role in seawater productivity. Limnol. Oceanogr. 48: 1557-1568.

Marshall, C. T., And R. H. Peters. 1989. General patterns in the seasonal development of chlorophyll $a$ for temperate lakes. Limnol. Oceanogr. 34: 856-867.

Martens, B. Goddeeris And G. Coulter [EDs.]. 1994. Speciation in Ancient Lakes. Arch. Hydrobiol.-Adv. Limnol 44, 317 pp. 
Matzinger, A., M. Jordanoski, E. Veljanoska-Sarafiloska, M. Sturm, B. Müller, And A. Wüest. 2006a. Is Lake Prespa jeopardizing the ecosystem of ancient Lake Ohrid? Hydrobiologia 553: 89-109, doi:10.1007/s10750-005-6427-9.

- Z. SPIrkovski, S. PAtceva, And A. Wüest. $2006 b$. Sensitivity of ancient Lake Ohrid to local anthropogenic impacts and global warming. J. Great Lakes Res. 32: 158-179.

Moosmann, L., R. Gächter, B. Müller, And A. Wüest. 2006. Is phosphorus retention in autochthonous lake sediments controlled by oxygen or phosphorus? Limnol.Oceanogr. 51: $763-771$.

—, B. Müller, R. Gächter, A. Wüest, E. Butscher, and P. Herzog. 2005. Trend-oriented sampling strategy and estimation of soluble reactive phosphorus loads in streams. Water Resour. Res. 41: W01020, doi:10.1029/2004WR003539.

Mortsch, L. D., AND F. H. Quinn. 1996. Climate change scenarios for Great Lakes basin ecosystem studies. Limnol. Oceanogr. 41: 903-911.

Müller, B., R. Stierli, AND A. Wüest. 2006. Phosphate adsorption by mineral weathering particles in oligotrophic waters of high particle content. Water Resour. Res 42: W10414, doi:10.1029/ 2005WR004778.

Naumoski, T. 2000. Phosphorus loading of Lake Ohrid. Ph.D. thesis, University "Sv. Kiril i Metodij". [In Macedonian.]

Ocevski, T., And H. L. Allen. 1977. Limnological studies in a large, oligotrophic lake (Lake Ohrid, Yugoslavia). Arch. Hydrobiol. 79: 429-440.

Omlin, M., P. Reichert, And R. Forster. 2001. Biogeochemical model of Lake Zürich: Model equations and results. Ecol. Model. 141: 77-103.

Patceva, S. 2001. The phytoplankton and the chlorophyll $a$ as indicators of the trophic state of the water in the littoral and pelagic region of Lake Ohrid. Master's thesis, University "Sv. Kiril i Metodij". [In Macedonian.]

- 2005. Comparative analysis of the phytoplankton community and the trophic state of Lakes Ohrid and Prespa. $\mathrm{Ph} . \mathrm{D}$. thesis, University "Sv. Kiril i Metodij”. [In Macedonian.]

ReIChert, P. 1994. AQUASIM - a tool for simulation and data analysis of aquatic systems. Water Sci. Technol. 30: 21-30.

Roelofs, A. K., And P. Kilham. 1983. The diatom stratigraphy and paleoecology of Lake Ohrid, Yugoslavia. Palaeogeogr. Palaeocl. 42: 225-245.

SalemaA, H. 1994. Lake Ohrid. In K. Martens, B. Goddeeris and G. Coulter [eds.]. 1994., Speciation in ancient Lakes. Arch. Hydrobiol.-Adv. Limnol. 44: 55-64.

Schelske, C. L., AND D. A. Hodell. 1995. Using carbon isotopes of bulk sedimentary organic matter to reconstruct the history of nutrient loading and eutrophication in Lake Erie. Limnol. Oceanogr. 40: 918-929.
SCHINDLER, D. W. 2006. Recent advances in the understanding and management of eutrophication. Limnol. Oceanogr. 51: 356-363.

Seehausen, O., J. J. M. vanAlphen, and F. Witte. 1997. Cichlid fish diversity threatened by eutrophication that curbs sexual selection. Science 277: 1808-1811.

Sell, J., AND Z. SPIRKovsKi. 2004. Mitochondrial DNA differentiation between two forms of trout Salmo letnica, endemic to the Balkan Lake Ohrid, reflects their reproductive isolation. Mol. Ecol. 13: 3633-3644, doi:10.1111/j.1365-294X. 2004.02362.x.

Shimaraev, M. N., V. I. Verbolov, N. Granin, and P. P. Sherstayankin. 1994. Physical limnology of Lake Baikal: A review. Irkutsk, Okayama. 80 pp.

Skoog, D. A., D. M. West, And F. J. Holler. 1996. Fundamentals of analytical chemistry, 7th ed. Saunders College Publishing.

Stankovic, S. 1960. The Balkan Lake Ohrid and its living world. Monographiae Biologicae, Vol. IX. Uitgeverij Dr. W. Junk, Den Haag, Netherlands.

Tsugeki, N., H. Oda, And J. Urabe. 2003. Fluctuation of the zooplankton community in Lake Biwa during the 20th century: A paleolimnological analysis. Limnology 4: 101-107.

Veljanoska-SARAFiloska, E. 2002. Nitrogen and phosphorus loading in Lake Ohrid influenced by Rivers Velgoska and Koselska. Masters thesis. University "Sv. Kiril i Metodij”. [In Macedonian.]

Vollenweider, R. A. 1969. Possibilities and limits of elementary models for lake material balances. Arch. Hydrobiol. 66: 1-36. [In German.]

WAGNER, B., AND OTHERs. In press. The potential of Lake Ohrid for long-term paleoenvironmental reconstructions. Palaeogeogr. Palaeocl.

WeISS, J. 2004. Handbook of ion chromatography, 3rd ed. Wiley$\mathrm{VCH}$.

Wüest, A., G. Piepke, and J. D. Halfman. 1996. Combined effects of dissolved solids and temperature on the density stratification of Lake Malawi. In C. T. Johnson and E. O. Odada [eds.]. 1994., Climatology and paleoclimatology of the East African lakes, p. 183-202. Gordon and Breach.

Wurtsbaugh, W. A., W. F. Vincent, C. L. Vincent, H. J. Carney, P. J. Richerson, and R. A. Tapia. 1992. Nutrients and nutrient limitation of phytoplankton. p. 147-160. In C. Dejoux and A. Iltis [eds.]. 1994., Lake Titicaca: A synthesis of limnological knowledge. Kluwer.

Received: 31 March 2006 Accepted: 20 July 2006 Amended: 1 September 2006 